\title{
Service-learning and critical thinking outcomes in general education courses
}

Larry J. Smith

West Virginia University

Follow this and additional works at: https://researchrepository.wvu.edu/etd

\section{Recommended Citation}

Smith, Larry J., "Service-learning and critical thinking outcomes in general education courses" (2014). Graduate Theses, Dissertations, and Problem Reports. 553.

https://researchrepository.wvu.edu/etd/553

This Dissertation is protected by copyright and/or related rights. It has been brought to you by the The Research Repository @ WVU with permission from the rights-holder(s). You are free to use this Dissertation in any way that is permitted by the copyright and related rights legislation that applies to your use. For other uses you must obtain permission from the rights-holder(s) directly, unless additional rights are indicated by a Creative Commons license in the record and/ or on the work itself. This Dissertation has been accepted for inclusion in WVU Graduate Theses, Dissertations, and Problem Reports collection by an authorized administrator of The Research Repository @ WVU.

For more information, please contact researchrepository@mail.wvu.edu. 
Service Learning and Critical Thinking Outcomes in General Education Courses

\author{
Larry J. Smith
}
Dissertation submitted to the College of Education and Human Services
at West Virginia University
in partial fulfillment of the requirements
for the degree of
Doctor of Education in

Educational Leadership Studies/Higher Education Administration

\author{
Ernest R. Goeres, Ph.D., Co-Chair \\ Daniel Hursh, Ph.D., Co-Chair \\ Patricia Obenauf, Ed.D. \\ John Oughton, Ed.D. \\ Terance Rephann, Ph.D. \\ Department of Educational Leadership Studies \\ Morgantown, West Virginia \\ 2013
}

Keywords: Service-Learning, Critical Thinking

Copyright 2014 Larry J. Smith 
Abstract

Service-Learning and Critical Thinking Outcomes in General Education Courses

by Larry J. Smith

American educational reformers have noted an urgent need to develop and integrate pedagogical practices that promotes real world experiences that engage students in service and develops critical thinking skills of students. The reemergence of servicelearning builds on an alternative vision of higher education that commenced with Dewey's theories of experiential learning. To meet the need of developing critical thinking skills among today's students, some researchers have proposed that integration of service-learning programs may produce a number of student learning outcomes, including critical thinking. Responding to calls for colleges to engage students in real world problems through service-learning, in 1985 Campus Compact a group of 3 colleges and universities was formed. Today there are 1,100 colleges and universities that are members of Campus Compact, educating over 6 million students. Notwithstanding these realities, there is scarce research examining the effects of service-learning on critical thinking in small sized public Campus Compact affiliated universities.

The purpose of this study was to examine the effect of service-learning on development of critical thinking among a sample of undergraduate students participating in service-learning courses at the Campus Compact-affiliated, public four-year, nonhistorically black university in Maryland with fewer than 5,000 students. This study utilized the California Critical Thinking Skills Test (CCTST) which provides clear delineation of subscales within critical thinking (analysis, evaluation, inference, and deductive and inductive reasoning).

This study addressed two research questions:

(RQ1) Does participation in general education courses that include servicelearning result in gains in critical thinking by students in the courses?

To answer (RQ1) statistical analysis were run with SPSS, (version 22). Aggregate data from pre-and post-test administrations were analyzed. The mean of the net difference in the scores, subscale scores, and total scores between the pre and post CCTST administrations were analyzed and examined by the Pre-Post test repeated measures main effect. Potential interaction of this factor with other variables (factors) was also examined by this ANOVA statistical analysis using SPSS (version 22). Results are considered statistically significant at the .05 alpha level.

(RQ2) Are there significant differences in critical thinking outcomes for male students as compared to female students in general education courses that include service-learning?

(RQ2) was answered by analyzing the aggregate data from the pre-post test administrations. The CCTST mean scores for male compared to female students in each of the CCTST subscales were analyzed. Results are considered statistically significant at the .05 alpha level. 
Conclusions

(RQ1) The findings from the ANOVA regarding the CCTST skills/scales results revealed that there was a trend toward significance with post-CCTST results being higher than pre-CCTST results. The findings from the ANOVA (overall changes) did not demonstrate a trend toward significance. However, the results were consistent with the skills/scales ANOVA and in the same direction. These findings are consistent with what some researchers have found in that service learning can indeed promote critical thinking.

(RQ2) The finding from the ANOVA regarding the skills/scales demonstrated statistically significant differences; however, these differences were primarily associated with the skills of Analysis and Deduction. The ANOVA (regarding the overall changes) revealed statistically significant differences between males and females in this study. While the gender effect was significant an analysis of covariance (ANCOVA) was also performed and revealed that whatever gender differences existed, they were not produced by the service-learning experience. The Significant Omnibus ANOVA regarding the skills/scales revealed the following ranked high to low: 1. Analysis, 2. Induction, 3. Inference, 4. Evaluation, and 5. Deduction.

Recommendations for Practice

$>$ Consider including assessment of the effect that service-learning has on Critical Thinking as a component of institutional assessment initiatives to inform ongoing development of best practices.

$>$ Consider developing longitudinal assessment of the gains in critical thinking outcomes that students make over the time of their entire collegiate experience.

$>$ Consider integrating curriculum and strategies that promote student development of a clear understanding of what constitutes critical thinking.

$>$ This study also recommends that colleges and universities consider providing professional development to practitioners that promotes emphasis on critical thinking outcomes across service-learning experiences that are integrated across the curriculum.

Recommendations for further Research

$>$ Further research is recommended that examines the longitudinal cumulative effects that service learning has on critical thinking and other outcomes.

$>$ Conduct further research which examines the effects of various types of servicelearning experiences.

$>$ Consider research examining diverse demographic institutions and populations that may further contribute to the body of knowledge of any cultural, demographic, or geographic effects of service-learning on critical thinking.

$>$ Provide further research of the effects of service-learning on student critical thinking outcomes within individual disciplines.

$>$ The increases in and sophistication of the CCTST skills found in this research suggests that further research be conducted that examines trends in student performance in each of the skill areas of: Analysis, Induction, Inference, Deduction, and Evaluation. 


\section{Dedicated to}

\section{Dedication}

It is an impossible undertaking to extend thanks and gratitude by dedicating this dissertation to all of those individuals without whom my survival and completion of this journey would not have occurred. Herein is my attempt, however humble and futile, at attempting impossible by expressing my gratitude by dedicating this work to those to whom I am eternally grateful.

Giving thanks always and for everything to God the Father in the name of our Lord Jesus Christ. Ephesians, 5:20

With all of my love, gratitude, mind, heart, spirit, and body I dedicate this dissertation to my beautiful wife, Nancy and my angelic daughter, Hannah. With your love, selfless sacrifice, unrelenting encouragement and support you helped me persevere when my body and spirit was broken. Our endless love and faith is the strength that sustains me each and every day. Thank you, my Nancy and my LB Hannah, our love and faith is force of my life. My love for you is incalculable and eternal. I am thankful for the blessing of you.

Love is patient, love is kind, It does not envy. It does not boast, it is not proud. It is not rude. It is not self-seeking, it is not easily angered, it keeps no record of wrongs. Love does not delight in evil but rejoices with the truth. It always protects, always trusts,, always hopes, always perseveres. Love never fails. I Corinthians 13: 4-8

To be sure, it is equally a Herculean task that I will never have the capacity to fulfill, to thank and dedicate this dissertation to Dr. Ernest Goeres and Dr. Dan Hursh , 
who co-chaired my dissertation committee. I would never have completed this journey without both of you.

My journey was impacted by struggles and strife that truly were unique to my journey. During these seemingly insurmountable times, when all appeared to be lost and it was as though I was a deeply submerged submarine with a screen door, you were both there for me with encouragement and guidance. With an unrelenting commitment you pushed me toward excellence, and scholarship. As we redefined “persistence,” you both selflessly invested in me your world-class scholarship, irreproachable experience and accomplished expertise. Through your generous spirit, I will reap the dividends from of the personal investment each of you made, in me, throughout this experience, for the remainder of my life. Dr. Goeres, thank you for giving me the benefit of your brilliant mind and sincere support in countless hours on the telephone and in person to make this study aspire for excellence, scholarship, and tenacity. Thank you also for your witty sense of humor. Dr. Hursh, thank you for your inspiration guidance, and unique ability to help others refine and extend thinking to examine a problem from $360^{\circ}$, this, too, is much of the reason my completion of this journey was made possible. Thank you both for being a lighthouse to me in the darkest and roughest of seas. I am both grateful and indebted to you and will never forget you.

I also dedicate with thanks and gratitude this dissertation to Dr. Patricia Obenauf and Dr. John Oughton of West Virginia University Department of Education and Human Resources. The selfless effort on the part of both of you to serve on my committee, are appreciated beyond words. Thank you both for your thoughtful sacrifice in supporting me in completion of my dissertation. Your valuable contributions added greatly to my 
study. Thank you to my childhood friend, Dr. Terance Rephann, of the University of Virginia. It has been a long road from our days as kids making forts in your yard to our days as undergraduate students having stimulating public policy discussions to today. Tempus fugit. Thank you Terry for your friendship in serving on my committee and for sharing your time, talent, and support that contributed greatly to helping me cross the rugged terrain and helped me see the summit.

The two most important words that can ever be offered are, "thank you.” Therefore, with all the gratitude in my heart, I dedicate with a profound "thank you," this dissertation to my brother, Dr. Leonard Lock of the Alabama Higher Education Commission. Lenny, you have selflessly and endlessly shared the gift of your friendship, support, guidance and expertise. I am forever grateful and blessed for our brotherhood. With humility and love I also thank and dedicate this dissertation to one of, "the greatest generation,” my father and hero, John F. and mother Kathleen L. Smith who helped me through the struggles of our own lives, in ways I could not see in my youngest years, strive to be the very best person, husband, and father I can be each and every day. I know you are both with me in spirit. This is dedicated to both of you and generations of our family who were denied the dignity of formal educational opportunity, not by choice, but by the horrific conditions and events of circumstance.

I also dedicate this dissertation with thanks to Barbara and Roy O. Taylor, Drs. Joy and Tom Mappes, Bernard Wynder, Dr. Elinor Burkett, Dr. Walter Lackey, Darothy Holmes, James E. Lyons, Ruth Pitzer, Gus Knieriem, David Potter, Rev. Steve McCarty, Mike Leith, Dr. Diane Blankenship, Michael P. Lewis, Randal and Tamara Taylor, Homer F. Berry, Dr. Phillip Allen, Captain Robert T. “Bo” Myers, USMC, Charles 
Stewart, Paula Swayne, and Dr. Barbara Ornstein. I have been blessed beyond measure in the gift of your friendship extended to me in the often difficult journey of my life. Although for much, by passing, time, distance our paths are no longer converged. . . they are forever intersected. Each of you perpetually shape me as mentors, teachers and friends who I count among the blessings of family.

I extend special thank you and further dedicate this dissertation to Ms. Char Allen, and Dr. Paul Chapman for your unwavering caring, guidance, assistance, and support that aided me in crossing the Rubicon.

I also offer my deepest gratitude and further dedicate this dissertation to the West Virginia University Department of Education and Human Resources for your unwavering support, and commitment, in particular Dean Lynne Schrum, Ph.D.. I am thankful, honored and humbled to have journeyed with this department that is an epicenter of world-class research, excellence, and innovation, that develops formidably skilled and talented practitioners that will continue to positively shape the State of West Virginia, the nation and our changing world.

With deep gratitude I dedicate this dissertation to each of you. Thank you for the blessings you extended to me that continue to shape me into the person I am through the continual process of becoming. I have tried not just to be part of the world, but to shape it. 


\section{TABLE OF CONTENTS}

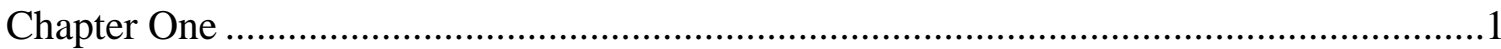

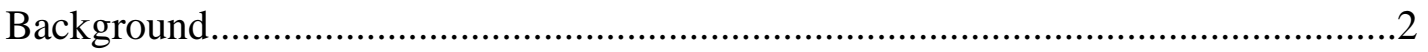

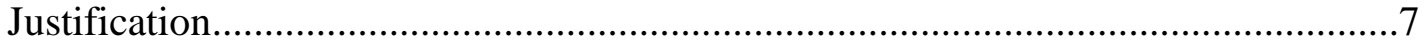

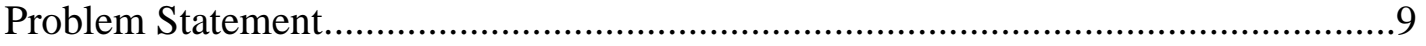

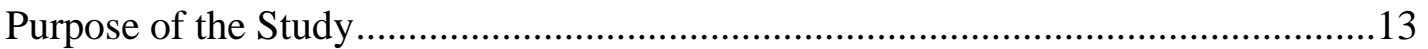

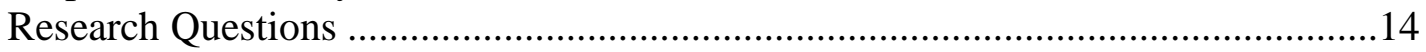

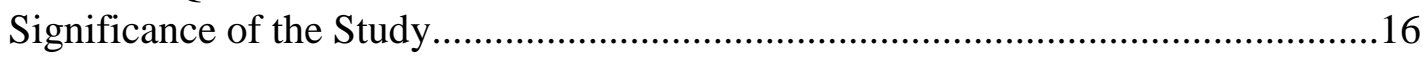

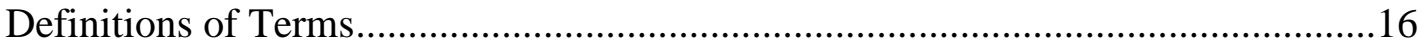

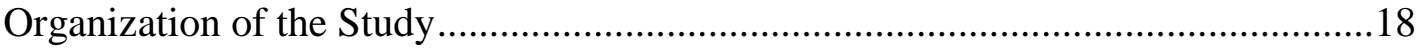

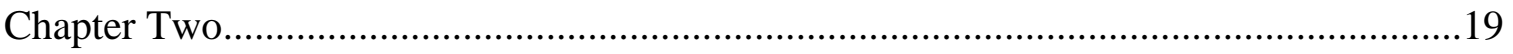

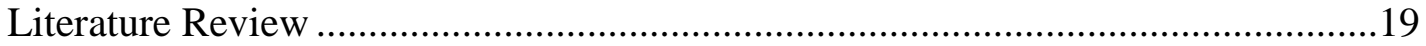

Service-Learning: Development and Criticism ..................................................19

Service-Learning and Learning Outcomes in Interpersonal Skills, Communication

Skills, Affective Values and Critical Thinking ...................................................36

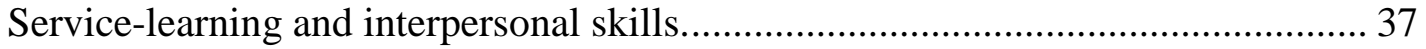

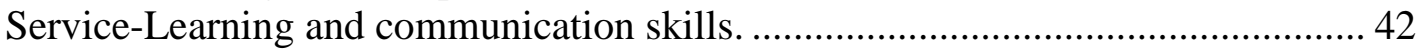

Affective outcomes (attitudes and values) of service-learning. ............................ 44

Critical Thinking and Service-Learning .......................................................... 51

Research regarding critical thinking and service-learning outcomes..................... 54

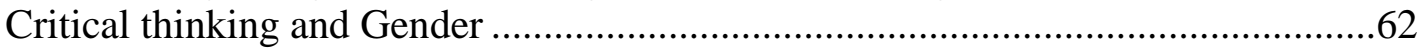

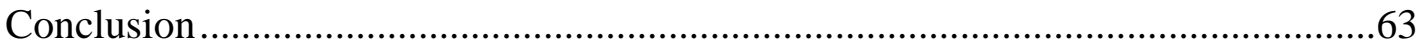

Research Questions ...........................................................................65

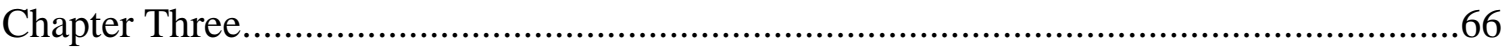

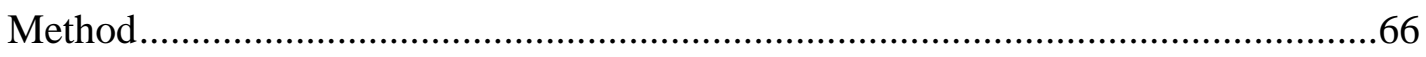

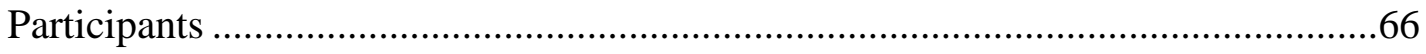

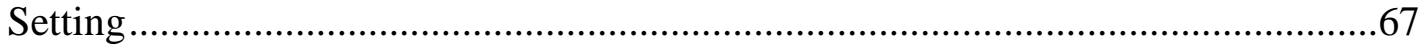

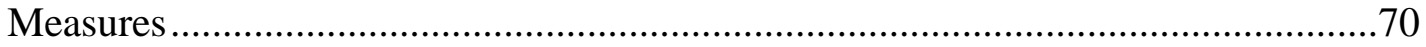

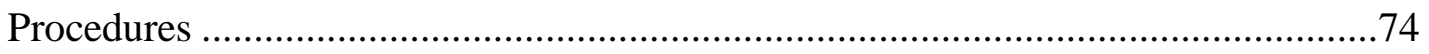

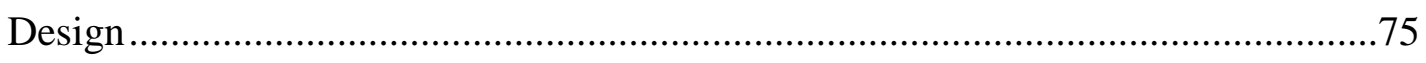

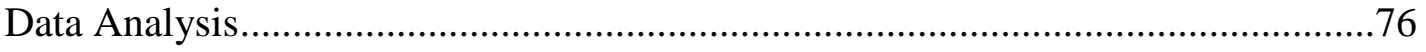




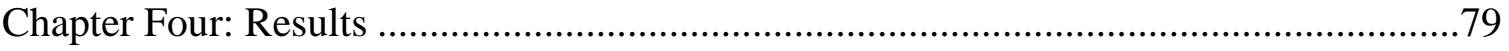

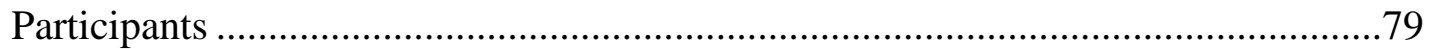

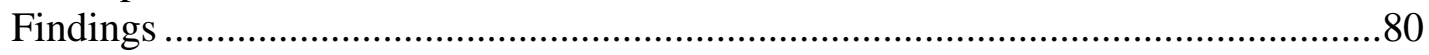

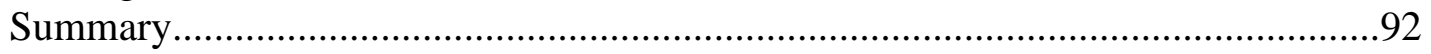

Chapter Five: Summary, Conclusions, and Recommendations..........................................93

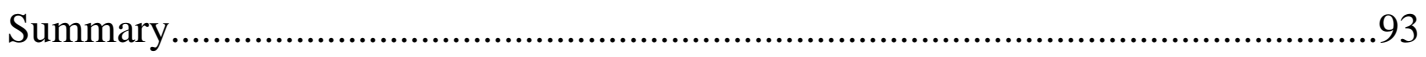

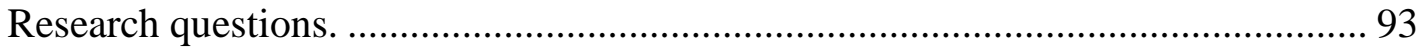

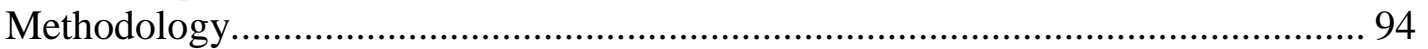

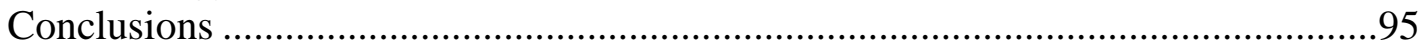

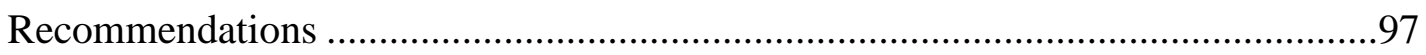

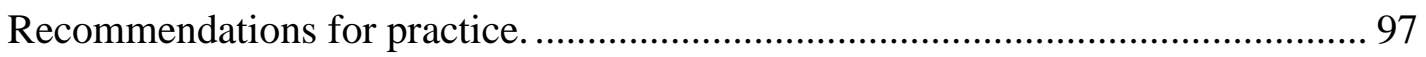

Recommendations for further research. ........................................................... 99

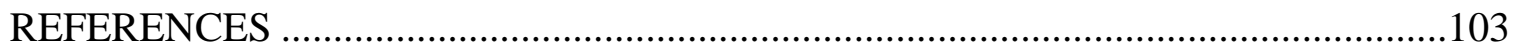

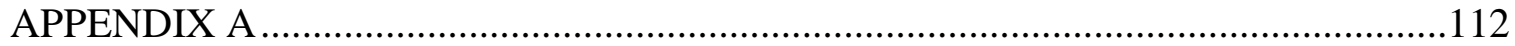

Pre Service-Learning Experience Cover Letter..................................................112

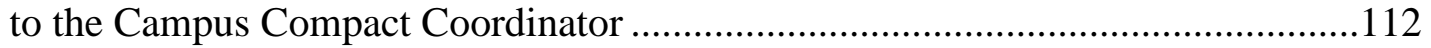

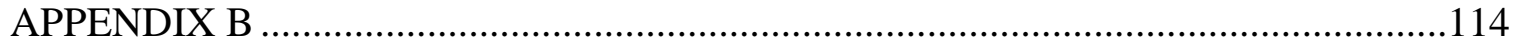

Campus Compact Coordinator Questionnaire......................................................114

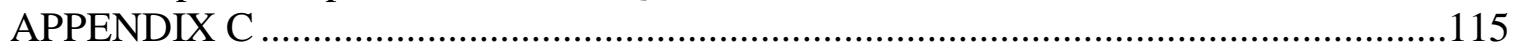

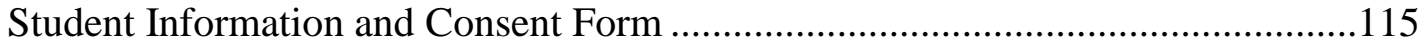

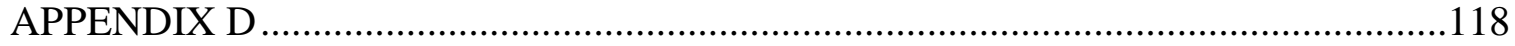

Post-test Cover Letter to Students.........................................................................118 


\section{LIST OF TABLES}

Table 1 Service-Learning in Higher Education Historical Timeline................35

Table 2 Maryland Campus Compact Institutions..............................68

Table 3 A Priori Power Analyses...........................................69

Table 4 Effects Analyzed by this Dissertation......................................76

Table 5 CCTST Mean Scores Sub-Scale by Pre-Post and Gender..................81

Table 6 Recoded Pre-Post Descriptive Statistics..............................82

Table 7 Recoded Descriptive Statistics........................................ 82

Table 8 ANOVA 1 - 2 (Pre-Post) by 5 (Type of Skill) by 2 (Gender) ANOVA with repeated measures on the first two factors. Tests of Within-Subjects Effects Recoded for Differing Scales...............................................84

Table 9 ANOVA 1 Tests of Between-Subjects Effects - Recoded for Differing Scales......................................................... 85

Table 10 Post hoc analysis after Omnibus ANOVA $1 \ldots \ldots \ldots \ldots \ldots \ldots \ldots \ldots \ldots . \ldots . \ldots . \ldots . \ldots . \ldots$

Table 11 Means of Skills - Descriptive Statistics-Recoded for

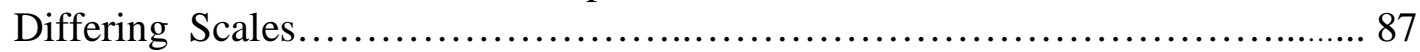

Table 12 Significant Omnibus ANOVA skills (scales)

Ranked from High to Low .87

Table 13 Means of skills by gender-Descriptive StatisticsRecoded for Differing Scales...............................................88

Table 14 T-tests for Gender Differences by Skill.............................88

Table 15 Descriptive Statistics for the OVERALL ANOVA

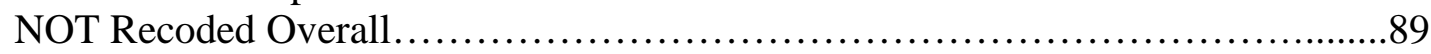

Table 16 Pre-Post- Descriptive Statistics for the overall ANOVA

Not Recoded Overall.......................................................89

Table 17 ANOVA 2 Significance of Pre-post Effect on Overall Score.................90 
Table 18 ANOVA 2 OVERALL -

Tests of Between-Subjects Effects.

Table 19 ANCOVA OVERALL-

Analysis of pre-test as covariate on post-test scores............................92

Table 20 Significant Omnibus ANOVA skills (scales)

Ranked from High to Low .................................................. 


\section{Chapter One}

American education is facing numerous challenges in a rapidly changing world economy. The advent of global interdependence and the ever-changing technology of the information-based international economy require higher education in the U.S. to make new efforts to ensure that graduates are prepared to thrive in today's world by meeting the needs of today’s students by providing “a curriculum that prepares them to assume enormous responsibilities of building a world while living in an old and rapidly changing society” (Levine \& Cureton, 1998, p. 166). As a result, a number of educators have called for greater accountability in education in making certain not only that student learning is occurring, but also that it is effective and useful (Smith, 2004, p.16). One study surveyed a wide range of undergraduates from 28 college campuses across the U.S., revealing that most students need new or added elements in their undergraduate education to prepare them for the changing world of today (Levine \& Cureton, 1998, p. 163).

The continuing emphasis on the quality of graduates from American universities and colleges has forced academe as a whole to examine "its effectiveness in achieving its most fundamental goal: student learning” (Jacoby, 2007, p. 3). Moreover, it is critical that learning is organized to “respond to the needs of today's students and tomorrow's, not yesterday’s” (Kellogg Commission, 1999, p. 2). Critics argue that the demands of the marketplace require that colleges shift the educational paradigm from one that provides instruction to one that is focused on producing learning (Barr \& Tagg, 1995, p. 12; Smith, 2004, p. 45). In the context of this shift, Ernest Boyer has called on higher education to renew its historic commitment to service and to the process of enhancing learning 
through experiences linked to student service (Boyer, 1990, p.2; Jacoby, 1996, p.75).

The Kellogg Commission specifically argues that one of the best ways to prepare students for the challenges of life is by "integrating the community with their academic experiences” (Kellogg Commission, 1999, p. vii). Service-learning is also important because it helps students better understand the "interdependent nature of our world" (Boyer, 1990, p. 77).

A number of colleges and universities have begun to implement innovative approaches that combine student learning and service. Service-learning, a pedagogical practice that reemerged at the end of the 1980s, has received considerable attention (Hollander \& Saltmarsh, 2005). More and more colleges and universities use servicelearning to promote student service and enhance student learning through experiences that link curriculum with community involvement (Ramaley, 1997, p.17; Jacoby, 2007, p. 99). Campus Compact, a major national organization that promotes service-learning, has increased its membership from its original six institutions, to 748 participating colleges in 2001 (Campus Compact, 2003; Crews, 2002, p.268).

\section{Background}

In the current educational climate, service-learning reform is conflated with the increased emphasis on critical thinking. The so-called banking model of education, whereby students sit and listen to lectures, is increasingly being challenged. Educational theorists like Paolo Freire argue that such a transmissionist model must be replaced with an experiential-based learning program "which permits the learner to make their [sic] way through the unknown, thus learning by becoming aware of and identifying the need for further knowledge” (Burr, 2002, p. 14). According to Freire, “knowledge emerges 
only through invention and reinvention, through the restless, impatient, continuing, hopeful inquirer” (Burr, 2002, p. 14). Critical thinking, it is increasingly being realized, is the essential element in this transformation. By studying how much students know and learn, cognitive scientists have confirmed that much of the knowledge that students uncritically store up in class is "quite useless to them when they are in new situations" (Eyler \& Giles, 1999, p. 8; Smith, 2004, p. 45). Studies confirm that "students rarely transferred knowledge from classroom instruction to new problems” (Eyler \& Giles, 1999, p. 8). If, however, students are engaged in a problem-solving situation and make repeated attempts to solve a problem through critical thinking, then they are far more likely to be able to apply what they have learned to other situations outside the classroom (Smith, 2004, p.33). This observation has naturally led some educators to argue that critical thinking develops best in experiential and even service-learning situations.

Service-learning, though cast into the shadows for over two generations in American academia, has a long history. The idea of service-learning as a valuable pedagogical methodology was first espoused by Dewey, who argued that students learn better when they apply their knowledge in real-world settings (Ehrlich, 1996, p. 17). Dewey was influenced by the Anglo-American tradition of philosophical pragmatism as exemplified by William James and Charles Sanders Pierce, who argued that experience is the "ultimate reality" (Burr, 2002, p. 2). The roots of this experiential approach to education lie deep in the apprenticeship tradition, and, in America, can be found in the progressive ideas of Benjamin Franklin. These roots can also be found in the ideas of Thomas Jefferson who was deliberate and strategic in his efforts to create a "broadly conceived democratic educational system” in which the cultivation of learning would 
provide the necessary nourishment to sustain liberty (Peterson, 1970, p. 357). However, in the aftermath of World War II, Robert M. Hutchins and Mortimer Adler argued that it was more important for college students to absorb a canon of great books from great minds.

The reemergence of service-learning builds on an alternative vision of higher education that commenced with Dewey's theories that "learning is a wholehearted affair, linking emotions and intellect” (Eyler \& Giles, 1999, p. 8). Dewey’s argument that “students learn best not by reading great books in a closed room but by opening the doors and windows of experience” (Ehrlich, 1996, p. xii) was particularly well-received in the 1960s. Dewey’s notion of the “experiential continuum” in which one creates new ideas by building on previous experiences and then reflecting, guided by teachers, on new experiences, was implemented in classrooms (Giles \& Eyler, 1994, p. 78). Smith argues that America's colleges and universities are failing our nation, in part, because they "still operate on the assumption that all important teaching and learning happens in classrooms” (Smith, 2004, p. 13). Whitehead likewise fears that too much classroom learning, administered primarily by means of lectures, transmits only "inert knowledge” to students, that is, knowledge that students may have had little use for in life (Eyler \& Giles, 1999, p. 8). Studies today confirm that students learn little listening to lectures that simply impart facts that students are then expected to memorize for tests (Eyler \& Giles, 1999, p. 8; Springer, 2007, p. 5).

In the 1970s, service-learning was invigorated by the emergence of the experiential educational theory derived from psychology and sociology. Experts in these fields felt that college was not teaching students how to be full, well-rounded human 
beings, but in fact were "denying (students) an active and valued role in (society)” (Conrad \& Hedin, 2003, p. 1). Moreover, it was felt that students graduating from college were “information rich and action poor” (Conrad \& Hedin, 2003, p. 1).

As a result, the experiential education movement grew and in the 1980s merged with the Wingspread conference initiative that sought to make college education more meaningful. The goals of the Wingspread conference were to take values seriously, put student learning first, and create “a nation of learners” (Jacoby, 1996, p. 20). Based on Chickering's ideas of what makes education meaningful, Wingspread encouraged more student-faculty contact, more cooperative learning between students, and more instances of active learning. Wingspread also adopted Allport's contact theory that service-learning between students and persons in disadvantaged communities could help reduce the prejudices ingrained in students by sheltered upbringings (Erickson \& O’Connor, 2000, p. 27). In the context of Wingspread, then, service-learning also came to be implemented as an "anti-prejudice tool” so long as the students are learning as much from the served community as the community learns from students. As part of this more structured approach to community action derived from the critical education theory of Gramsci, Freire, and the Frankfurt school, the service-learning curriculum analyzes social conditions and seeks to "achieve a deepening awareness of . . . the socio-cultural reality that shapes their lives” (Rosenberger, 2000, p. 36). Through rigorously structured contact, the Wingspread-derived service-learning avoided the pitfalls of "false generosity" and the reproduction of social power relations through the privileged merely helping the less privileged (Rosenberger, 2000, p. 33; Fink, 2003, p. 58). 
Campus Compact began in the late 1980s in response to the popular notion that a generation of college students was too "me-centered" and needed to be encouraged to serve communities more. Campus Compact created programming that helped students "be part of something larger than themselves" (Ehrlich, 1996, p. xii). A special emphasis in the Campus Compact programming was that the service-learning be carefully and structurally embedded into the curriculum. Its programs were also modeled on the ideas of Chickering and promoted engagement, collaboration, and active learning. Campus Compact had considerable success in enlisting colleges all over the U.S. in the servicelearning movement (Ehrlich, 1996, p.2). Since the 1980s, Campus Compact has remained at the vanguard of developing service-learning best practice (Crews, 2002, p. 268).

In recent decades, the service-learning model has been used as an anti-prejudice tool to reduce stereotypes and to open up communication between diverse populations (Erickson \& O’Connor, 2000. p.26). Empirical evidence suggests that service-learning programs that involve community services with disadvantaged populations do cause students to question their previously held beliefs about diverse communities and to amend and change views. On the basis of this kind of finding, other studies (Eyler \& Giles, 1999, p. 8; Giles \& Eyler, 1994, p. 78; RAND, 1999, pp. 6-9; Astin \& Sax, 1998; Jacoby, 2007, p. 99) have found that service-learning in general not only has a positive impact on the learning outcome of students, but also helps students in improving interpersonal and communication skills, affective values, and critical thinking skills.

The emphasis on critical thinking in service-learning derived from prior focus on the importance of reflection, going back to Dewey. In most service-learning programs implemented according to best practices, reflection is held to be "the vital link between 
service and learning” (Eyler \& Giles, 1999, p. 2; Kelshaw, Lazarus, Minier, 2009, p. 170). Although too many models of service-learning fail to live up to the balance of action of reflection required by service-learning best practice, the growing emphasis on critical thinking and problem solving has pushed service-learning in a new, more critical direction.

Moore and Parker assert that "critical thinking is the careful application of reason in the determination of whether a claim is true” (Moore and Parker, 2009, p. 3). The essential tool used to make "better judgments is critical thinking” (Moore and Parker, 2009, p. 2). The intentional integration of theory and practice linking institutions of higher education with the community is essential to ensuring that "genuine learning" responds to the needs, knowledge and potential of students” in order for them to become “equipped for work and service to their community” (Smith, 2004, p. 13). At present, service-learning initiatives that necessitate the development of critical thinking by students are the best hope for educating students who will then be able to function effectively in today’s complex and changing world (Smith, 2004, p. 17; Kelshaw, Lazarus, \& Minier, 2009, p. 173).

\section{Justification}

Research is needed to examine the connection between service-learning and development of critical thinking skills in students enrolled in colleges and universities. At present, most of the existing assessments regarding the value of service-learning are linked to reform initiatives, whether Wingspread, Campus Compact, the engaged campus, or experiential education. Responding to criticism, service-learning has developed over the years an elaborate arsenal of various practices, each one developed to address the 
“confusion over what experiential education is and how it differs from other approaches” (Conrad \& Hedin, 2003, p. 2). Although it is a positive development that "a diverse group of scholars and community partners committed to addressing a range of social concerns” (p.6) are involved in the continued development of theory and practice in servicelearning, most assessments of the learning outcomes of service-learning are connected to these reform initiatives (Heffernan, 2001). It is open to question whether a programmatic response to criticism such as Campus Compact, busily implementing and fine-tuning service-learning programs, can turn around and offer a fair assessment of the learning outcomes of programs it had a part in putting in place. Wingspread has emphasized creating a sustainable program in service-learning with monitoring and assessment being part of this effort. This approach helps to keep service-learning focused on its prescribed goals, but whether an assessment in such a programmatic context amounts to a fair appraisal of critical thinking development that takes place in the program, is also a question. Too many other programs developing service-learning modules are focused solely on redressing previously observed problems that community service programs did not ensure that significant learning occurred (Jacoby, 1996, p. 12).

The Faculty Casebook on Community Service Learning is, by contrast, concerned with safeguarding the academic integrity of service-learning programs by insisting that the credits given for service-learning are for the learning that occurs, and "not the service” (Mintz \& Hesser, 1996, p. 31). In this approach, institutional commitment to service-learning is found to be a significant factor in measuring whether learning has occurred. Overall, however, it can be argued that the assessment of service-learning at present remains too involved in the programmatic implementation of a viable program 
and thus may lack sufficient objectivity to offer fair and accurate appraisal of learning and critical thinking.

\section{Problem Statement}

Although service-learning has been highly influential on college campuses, its implementation and potential growth continue to be hindered by two interrelated problems. First, even though service-learning has been infused in numerous programs, as yet a single definition of service-learning remains elusive. Sigmon (1996) has noted that

“a distinctive aspect of the evolving nature of the 'movement' of service-learning is that no one definition will work for everyone” ( p.9). The American Association of Higher Education has defined service-learning as "a method under which students learn and develop through thoughtfully-organized service that is conducted in and meets the needs of a community and is coordinated with an institution of higher education” (AAHE, 1995, p.72). However, researchers continue to differ on which aspect of service-learning is the most pedagogically useful to students. Some teachers focus on the social value of service, while multiculturalists have explored the potential of service-learning to make all students more sensitive to diversity. Others argue that service-learning is most effective in developing social skills in a more well-rounded student; others focus on critical thinking skills.

In addition to difficulties establishing a firm definition of the parameters of service-learning in terms of its educational value, the literature on service-learning continues to be plagued by some fundamental questions about the nature of the effect that service-learning has on development of critical thinking. For service-learning, the question of effectiveness has been a chronic irritant. The entire service-learning initiative 
of the 1960s, for example, finally languished because it was determined that not only was the structure of the experiences paternalistic, entailing inherently uneven relationships between the college students and the persons they were helping, but also little learning was happening. As a result of these well-intentioned but misguided programs, the programs ended up only reaffirming, rather than counteracting, stereotypes, and only confirmed (or, in the terms of critical education theory, reproduced) preexisting power relations based on race, class, and gender (Jacoby, 1996, p. 11; Jacoby, 2007, p. 47). Moreover, many of the programs simply consisted of students going out into the community, without any effort made to link service to a curriculum. As a result, many educators began to argue that no learning was occurring during the programs. This alerted researchers to the fact that "the service experience does not ensure that either significant learning or effective service will occur” (Jacoby, 1996, p. 12). As a result of these criticisms, Sigmon, in particular, set about establishing a more theoretically grounded conceptualization of service-learning, thereby laying down principles that have since become the basis of all service-learning programs. According to Sigmon, learning can occur in service-learning programs only if "those being serviced become better able to serve and be served by their own actions, and those who serve also are learners and have significant control over what is expected to be learned” (Mintz \& Hesser, 1996, p. 29). By emphasizing that "all persons of are of unique worth" (p.43) a more rigorous sense of the mission of service-learning was established (Myers-Lipton, 1994)

As a result of previous questions about the effectiveness of service-learning as a learning module, service-learning today is more rigorously structured. Most servicelearning programs are integrated into a curriculum, and students learn from the 
experiences by engaging in carefully structured reflective sessions. Indeed, in today’s educational world, "the hyphen in service-learning is critical in that it symbolizes the symbiotic relationship between service and learning” (Jacoby, 1996, p. 6). The most optimal service-learning programs today make use of student reflection involving Kolb’s learning cycle. Service-learning programs today have focused on avoiding the pitfalls of paternalism by “demanding reciprocity between the server and the person or group being served” (Jacoby, 1996, p. 7). Today, “all parties in service-learning are learners and help determine what is to be learned” (Jacoby, 1996, p. 7). This means that most of the time the community being helped decides the tasks involved in the service-learning, and programs take extra care to make sure that the stated needs of those served are met. By clarifying these conceptual and procedural problems, many now argue that "service will go a long way in responding to higher education's critics who bemoan its fortress mentality in isolating itself from the encroaching problems of both its local communities and the rest of the nation” (Jacoby, 1996, p. 4).

The problem of whether service-learning actually leads to development of critical thinking is more urgent, given the accountability climate of higher education today. A number of studies (Eyler \& Giles, 1999, p. 8; Giles \& Eyler, 1994, p. 78; Astin \& Sax., 1998) have found that service-learning does have notable intrinsic benefits to the student, especially if the service-learning component is carefully integrated into the curriculum; then service-learning has been shown to produce concrete learning gains. However, many educators continue to suspect that service-learning amounts to educational "fluff” (p. 17) and that it continues to fail to develop an adequate theoretical basis and falls short in empirical proof of its impact on development of critical thinking (Giles \& Eyler, 1994). 
Added to this overall problem, many educators question how one assesses the amount of learning that a student experiences in the service-learning context. To address this problem, the field has imported a number of assessment techniques from other fields into classroom assessment of service-learning. These assessment techniques may entail review of a student's notebook, student self-reporting, self-reflection sessions involving an evaluation of the program, and student feedback on the work involved in servicelearning (Palomba \& Banta, 1999, p.72). Post-event gatherings at which the students share their opinions of the experience have also been found to be helpful. Some educators assess service-learning based on specific areas of improvement, with some reviewing the impact of service-learning in the development of student interpersonal skills, the impact of service-learning on student communication skills (Jones, 1996, p.25), the impact of service-learning on student citizenship ideas and caring about society, or whether servicelearning helps students develop a more authentically raised consciousness in terms of multiculturalism (Erickson \& O’Connor, 2000, p.42). Finally, a number of contemporary researchers have focused on whether service-learning improves the critical thinking skills of students.

A number of more targeted studies examined the link between learning and service in service-learning. One longitudinal study found that service-learning students at a number of institutions of higher education showed significant positive effects on eleven outcomes of student learning after being involved in service-learning (Astin \& Sax, 1998). Eyler and Giles’s (1999) study of the effectiveness of student learning examined student beliefs about learning. A 1999 RAND study also compared students who had taken service-learning courses with those who had not and found that, when good 
practice was used, there was a correlation between taking service-learning courses and academic standing. Although this research indicates that service-learning does improve learning, it does not examine the impacts of service-learning on various types of learning or critical thinking skills.

Moreover, a number of additional studies undertaken to assess these various measures of learning have found mixed results. A number of studies have shown that although students clearly enjoyed service-learning experiences more than they did classroom work, whether they actually learned anything remains difficult to determine. One key study found that students who took a service-learning course only maintained the status quo in terms of their critical thinking skills (Eyler \& Giles, 1999, p. 124). This finding leads to the conclusion that at present, "service-learning in and of itself was not a predictor of change in critical thinking” (Eyler \& Giles, 1999, p. 124).

As a result of the tenuous nature of proofs of learning in service-learning, the problem of determining whether critical thinking occurs in service-learning remains open and challenging. This study explores the problem of service-learning accountability by making use of an instrument to find a way to concretely measure critical thinking in service-learning contexts.

\section{Purpose of the Study}

The purpose of this study was to examine the effect of service-learning on development of critical thinking among a sample of undergraduate students participating in service-learning courses at the Campus Compact-affiliated, public four-year, nonhistorically black university in Maryland with fewer than 5,000 students. This study utilized a concrete scale instrument, the California Test of Critical Thinking Skills, to 
measure the impact of service-learning on students' critical thinking skills. At present, in the ongoing discussion of the impacts of service-learning on student learning and development, most studies are overly focused on a single measure, and mostly from a rhetorical, not scale-measured perspective. By examining the different types of critical thinking outcomes that occur in various service-learning courses, it is hoped that this study will contribute to a new phase of research in which more concrete measures set the standard for measuring the learning effectiveness of service-learning on critical thinking.

\section{Research Questions}

This study examined the effect of service-learning on development of critical thinking among a sample of undergraduate students participating in service-learning courses at the Campus Compact-affiliated, public four-year, non-historically black university in Maryland with fewer than 5,000 students addressed the following research questions:

(RQ1) Does participation in general education courses that include servicelearning result in gains in critical thinking by students in the courses?

(RQ2) Are there significant differences in critical thinking outcomes for male students as compared to female students in general education courses that include service-learning?

General education courses, such as English 101 or Introduction to Education, were chosen as the sites for service-learning to enhance the generalizability of the results and to prevent the effect of specialization of field or major interfering with a general assessment of service and learning. 
The specific instrument used to measure whether critical thinking development has occurred as a result of the service-learning experiences is the California Critical Thinking Skills Test, chosen because its clear delineation of subscales within critical thinking (analysis, evaluation, inference, and deductive and inductive reasoning), because it has strong validity, and because it requires only forty-five minutes to administer. The focus on critical thinking as a measure of learning is consistent with the emphasis placed on critical thinking in current studies of service-learning. A number of instruments have been developed to measure critical thinking outcomes. The Watson Glaser Critical Thinking Appraisal, which goes back to the 1930s, scored critical thinking on the basis of whether students could make inferences, recognize assumptions in arguments, make deductions, and interpret and analyze data (Palomba \& Banta, 1999, p. 255). The Holistic Critical Thinking Scoring Rubric, created by Peter Facione in 1994, emphasized analysis and evaluation skills as the key elements of critical thinking. The California Critical Thinking Dispositions inventory focused on seven factors involved in critical thinking, including truth-seeking, open-mindedness, inquisitiveness, and maturity (Palomba \& Banta, 1999, p. 255). These and other scales have not, however, ended the debate over what constitutes critical thinking.

The clarity of the California Critical Thinking Skills Test recommends its use. Such a scale better predicts whether resultant critical thinking improvements will actually bear fruit in general education courses as a result of service-learning.

The use of the California Critical Thinking Skills Test (CCTST) was preferred as the intent of the study is to discern a trend of improved critical thinking outcomes from the Campus Compact-affiliated, public four-year, non-historically black university in 
Maryland with fewer than 5,000 students. The CCTST was administered by the researcher who administered pre-and post- assessments, on site at the selected institution. The data analysis was run with the Statistical Program for the Social Sciences (SPSS Version 22). The results were broken down to obtain concrete measures of critical thinking outcomes for gender.

\section{Significance of the Study}

It is hoped that this study will be significant by redirecting the literature of assessment of service-learning away from a programmatic-based approach to a more generalized approach focused solely on independent measures of critical thinking.

This study examined a number of service-learning programs under the rubric of Campus Compact, using a scale measure that is not specifically linked to any program, to measure whether any critical thinking development occurred in the service-learning programs.

\section{Definitions of Terms}

Campus Compact: An initiative in service-learning implementation on campuses across the country that promotes the concept of the engaged campus through programs designed to encourage active citizenship among students.

Critical education theory: Derived from Gramsci, Freire, and the Frankfurt School, critical education theory examines how the educational system reproduces power relations from generation to generation, necessitating the development of rigorous critical thinking to counteract prejudice and raise consciousness.

Critical thinking: Currently taken to be the measure of learning in studies of learning outcomes, and consisting of a student's ability to analyze, assess assumptions, and 
induce and deduce conclusions as a result of engaging with and reflecting upon a problem.

Learning cycle: As originally developed by Kolb and utilized in Campus Compact service-learning, a learning cycle involves studying a problem, deriving a hypothesis about it, testing the hypothesis, and reflecting on the results. When used in the context of service-learning, the learning cycle involves critical thinking and is believed to lead to positive learning outcomes (Campus Compact, 2003, p. 46).

Problem-based service-learning: A service-learning course focused on a specific community program, with students working with community members to understand the problem involved (Heffernan, 2001, p. 3).

Pure service-learning: A service-learning course in which service as an idea is at the “intellectual core” of the course (Heffernan, 2001, p. 3).

Service-learning: An educational paradigm in which community service embedded in the structure of the curriculum is believed to enhance student critical thinking (Eyler and Giles, 1999, p. 117).

Wingspread: Named after the Wingspread Conference of the 1980s, and the publication, The Principles of Good Practice for Combining Service and Learning, a Wingspread-based service-learning module establishes a rich learning environment, includes training and monitoring of progress, and embeds the service-learning experience in an academic course curriculum (Mintz \& Hesser, 1996, p.31). Wingspread’s principles were instrumental in improving the validity of service-learning by mandating that student and community, based on Allport's 
contact theory, establish equal relations and work together to solve problems, a process that prevents the development of paternalistic service which has been found to only reinforce stereotypes.

\section{Organization of the Study}

This study consists of five chapters. Chapter 1 consists of an introduction, justification, problem statement, research questions, and definitions. Chapter 2 reviews relevant literature and theory as it relates to service-learning in higher education. Chapter 3 outlines the design and methodology of this study. Chapter 4 presents the findings and results of the research. Chapter 5 will present a summary of the study, conclusions, and recommendations for practice and further research. 


\section{Chapter Two \\ Literature Review}

\section{Service-Learning: Development and Criticism}

Service-learning as a paradigm for educational reform has its roots in the experiential learning theories of John Dewey, whose case studies of students engaged in community service and action-oriented learning experiences in the 1930s proved that students learn better when they apply their knowledge in real-world settings (Dewey, 1938, p. 96; Ehrlich, 1996, p. 2). Influenced by James and Pierce, philosophical pragmatists who argued that experience is the "ultimate reality” (Burr, 2002, p. 2), Dewey adopted a secondary strain of American educational theory going back to Benjamin Franklin, which was decidedly at odds with "most classroom approaches where knowledge is acquired through abstract environments” (Burr, 2002, p. 3). Dewey’s progressive ideas were also at odds with those of Hutchins and Adler at the University of Chicago, who believed that the best way for college students to learn was to absorb a canon of great books from great minds, an argument that more or less "won the day" and had a long-lasting influence on higher education in the United States. Yet Dewey was a highly influential “public intellectual” (Ehrlich, 1996, p. xi), and his ideas had a significant impact, if mostly outside the field of education.

Dewey’s fundamental idea was that learning happens when there is an “interaction of knowledge and skills” in the context of an experience (Ehrlich, 1996, p. xii). That is, "students learn best not by reading great books in a closed room but by opening the doors and windows of experience” (Ehrlich, 1996, p. xii). Moreover, the character of such learning, because based in experience, is of a problem-solving 
orientation, as in an experiential situation "learning starts with a problem and continues with the application of increasingly complex ideas and increasingly sophisticated skills to solve increasingly complicated problems” (Ehrlich, 1996, p. xii). The key structure of Dewey's philosophy of experience was the "principle of continuity” which stated that "all experience occurs along a continuum called the experiential continuum” in which one creates new ideas by building on previous experience and then reflecting, guided by teachers, on new experiences (Giles \& Eyler, 1994, p. 78). Indeed, learning does not occur simply by experiencing something, but happens when there is a dynamic interaction of “action and reflection” (Eyler \& Giles, 1999, p. 8). Only by reflecting upon practice in a structured environment can a student devise more sophisticated responses to problems in life (Kelshaw, Lazarus, \& Minier, 2009, p. 170). An additional aspect of Dewey’s learning theories is that "learning is a wholehearted affair, linking emotions and intellect, (and that) an educative experience is one that fosters student development by capturing student interest . . . because it deals with a problem that awakens student curiosity” (Eyler \& Giles, 1999, p. 8).

The significance of Dewey's theories, then and now, was that his ideas counteract a theory of learning that, still dominant in higher education today, has been critiqued for a century. Educators have repeatedly worried that too much of what college students learn is what Whitehead termed "inert knowledge" that the student may have little use for in life (Eyler \& Giles, 1999, p. 8; Springer, 2007, p. 5). This idea is being reaffirmed in studies today that increasingly reveal that students learn little listening to lectures that impart facts that the students are then expected to memorize and repeat back in tests (Eyler \& Giles, 1999, p. 8; Merizow \& Taylor, 2009, p. 7). Indeed, Dewey was an 
important figure in this line of reasoning, as he did not believe that memorizing materials from classroom lectures did, in fact, constitute learning (Eyler \& Giles, 1999, p.9). In contrast to classroom learning, Dewey argued that students learn much more effectively when mind and heart are engaged in the problem of an experience (Eyler \& Giles, 1999, p.7).

Dewey’s ideas languished in the 1960s, when they received a boost from the activist nature of educators at the time. Indeed, the term service-learning was coined by Robert Sigmon at the Southern Regional Education Board in 1967 (Jacoby, 1996, p.11). Sigmon drafted principles for service-learning that continue to "underlie most subsequent sets of service-learning principles” (Mintz \& Hesser, 1996, p. 29). Sigmon formulated his principles for service-learning at the climax of a period of community service initiatives in higher education, most of which floundered on the "pitfalls of helping others or doing good” (Jacoby, 1996, p. 12). Too many of the programs devised by educators in the 1960s suffered from a paternalistic outlook, where students and service-receivers existed in an uneven relationship with those being served, resulting in cases where, while wellintentioned, the programs only reaffirmed stereotypes and power relations based on race, class, and gender (Jacoby, 1996, p.12). Moreover, the learning being done in too many of the community service programs in the 1960s was being questioned, and many educators were coming to the conclusion that "the service experience does not ensure that either significant learning or effective service will occur” (Jacoby, 1996, p. 12). As a result of these criticisms of community service, Sigmon developed the more theoretically grounded notion of service-learning (hyphen included) and established principles that have since become the basis of all service-learning programs. According to Sigmon, 
learning can occur in service-learning only if "those being serviced become better able to serve and be served by their own actions, and those who serve are also learners and have significant control over what is expected to be learned” (Mintz \& Hesser, 1996, p. 29). Sigmon believed that this approach to service-learning also opens up students' eyes to the fact that "all persons of are unique worth” (Myers-Lipton, 1994, p. 43). Only by helping one another in service, he argued, can planet earth itself be saved (Myers-Lipton, 1994, p.43). Wells and Knefelkamp argue that theory can be developed only "out of hands-on experience.” Sigmon’s formulation of service-learning also entailed a more rigorous sense of how learning derives from experience (Mintz \& Hesser, 1996, p. 29).

In the 1970s, service-learning resurgence was aided by the development of the experiential education reform movement (Conrad \& Hedin, 2003, p.72). Experiential education theory derives from both psychology and sociology, as concerned experts in both fields felt that college was not teaching students how to be full, well-rounded human beings, but rather "insulting the young and denying them an active and valued role in it" (Conrad \& Hedin, 2003, p. 1). Moreover, college as it is normally configured does not offer students many opportunities to “demonstrate their worth” (Conrad \& Hedin, 2003, p. 1). Many argue that the absence of experiential opportunities in the community fails students and is "justified by tradition" rather than "characterized by value” (Smith, 2004, p. 13). The graduates coming from colleges overly focused on classroom learning are, as a result, “information rich and action poor” (Conrad \& Hedin, 2003, p. 1).

In the 1980s, Sigmon’s ideas were reaffirmed by the Wingspread conference, which, in the context of a broader reform initiative to make college education more meaningful, restated the principal ideas underlying effective service-learning. 
Wingspread's ideas were founded in the context of reform at the time and dominated by the issues of "taking values seriously, putting student learning first, and creating a nation of learners” (Jacoby, 1996, p. 20). Chickering’s seven principles for the overall improvement of college education are suffused through Wingspread's formulation of service-learning. Chickering argued that for college education to be more meaningful to students there must be more student-faculty contact, more cooperative learning between students, and more instances of active learning. It is also important that students spend more time on task and receive quick feedback by teachers who communicate high expectations to them, and that the teachers and colleges also "respect diverse talents and ways of learning” (Jacoby, 1996, p. 21).

In the context of reforms initiated by Wingspread, Campus Compact was begun in the mid-1980s in response to the popular notion that the current generation of college students were too me-centered, and to create programming that would allow students to show how "eager to help others and to be part of something larger than themselves" (Ehrlich, 1996, p. xii). Campus Compact had immediate and considerable success in enlisting colleges all over the United States in the service-learning movement (Ehrlich,1996, p. xii). The primary guiding principle of Campus Compact, derived from Wingspread, is that service-learning be carefully and structurally embedded into the curriculum. Campus Compact initiated programming modeled on ideas of engagement, collaboration, and active learning as spelled out by Chickering. Since the mid-1980s, Campus Compact has remained at the forerunner of developing service-learning best practices (Crews, 2002, p. 268). 
Service-learning theories have also received support from critical education theorists, who also argue that higher education as presently practiced, with students taking notes from lectures and then regurgitating the notes in tests, hardly qualifies as learning. Critical education theorists are concerned that the current "banking model" of education implicitly claims that "knowledge is created and possessed by an expert" (Myers-Lipton, 1994, p. 40). Moreover, most lecture-format learning ends up compartmentalizing knowledge. Both aspects of education today "produce a person who does not question and who is alienated” (Myers-Lipton, 1994, p. 40). These ideas are more or less affirmed by the criticism launched against Western education by the Indian activist Gandhi. He felt that as currently practiced, education may train people for occupations, but not "help people solve problems in the community” (Myers-Lipton, 1994, p. 40). As a result, "Western education fills us with discontent, and providing remedy for the discontent, have made us despondent” (Myers-Lipton, 1994, p. 40).

What distinguishes contemporary service-learning from its forerunner in experiential education is that the service is integrated into curriculum, and students learn from the experience by engaging in carefully structured reflective sessions. Indeed, "the hyphen in service-learning is critical in that it symbolizes the symbiotic relationship between service and learning” (Jacoby, 1996, p. 6). While using a wide range of methodologies, most optimal service-learning programs today enlist the students in reflection. Informed as well by Kurt Lewin's notion of the learning cycle, moving from concrete experience, to reflections on the experience, to synthesis and abstract conceptualization (Jacoby, 1996, p.7), service-learning has developed a much more rigorous structure. 
A second key characteristic of contemporary service-learning practice is that it has worked hard, theoretically and practically, to avoid the pitfalls that result from unequal relationships during the service experience. Service-learning today steers clear of paternalism by demanding "reciprocity between the server and the person or group being served” (Jacoby, 1996, p. 7). Today, “all parties in service-learning are learners and help determine what is to be learned” (Jacoby, 1996, p. 7). In all best practice service-learning programs, it is the community that decides what the service tasks will be, and all programs take care to ensure that the services offered thus actually meet a real need, and do not simply correspond to vague student desires to help people (Jacoby, 2007, p. 75, Smith, 2004, p. 17). Whether the service-learning experience is a long-term or short-term project, or is held to varied educational outcome measures, all service-learning programs today seek to maintain rigor by mandating reciprocity and equality of all learners (Palomba \& Banta, 1999, p. 67; Jacoby, 2007, p. 99).

Indeed, many practitioners today argue that service-learning itself is “a perspective and a process” (Boyle-Baise \& Efiom, 2000, p. 212). Because servicelearning often brings students in contact with diverse populations, multiculturalist educators have also begun to offer programming in service-learning. Because so many theoretical threads are converging on service-learning, many educators believe that service-learning has "tremendous potential as a vehicle through which colleges and universities can meet their goals for student learning and development while making unique contributions to addressing community, national and global goals” (Jacoby, 1996, p. xvii). Service-learning, some argue, may even help transform the character of higher education. Jacoby argues that "a renewed commitment to service will go a long way in 
responding to higher education's critics who bemoan its fortress mentality in isolating itself from the encroaching problems of both its local communities and the rest of the nation” (Jacoby, 1996, p. 4). It appears that the service-learning movement is having an effect on changing student commitment to society, with $70 \%$ of students (in 1996) reporting that they had engaged in volunteer work while in high school, and 68\% of students in universities reporting that they had volunteered or participated in servicelearning activities of some sort (Jacoby, 1996, p. 6).

More pertinent to the continuation of service-learning, in today’s accountability climate in education, is whether service-learning in fact helps students learn more and improves their academic achievement in college. This remains a contested issue. However, a key study of Campus Compact service-learning programs did find that "the academic payoffs of having students engage in community service are substantial when the service activity is integrated with traditional classroom instruction” (Markus \& Howard, et. al., 1993, p. 2). The findings of this study indicated that integration is the key variable, as only when time was set aside for the service-learning students to "reflect upon and discuss what they are learning in the community” (Markus \& Howard, et. al., 1993, p. 2), does service-learning produce concrete positive learning gains. More concrete findings are desired, as too many educators continue to criticize service-learning programs as “fluff” (Giles \& Eyler, 1994, p. 17). It is likely that such criticism continues to haunt service-learning because, to date, the service-learning field has failed to develop an adequate theoretical basis, and because there remain too few studies reporting concrete positive outcomes from student participation in service-learning. 
In response to criticism, the service-learning field has worked to create a model for best practice. So many strands of educational theory have flowed into the servicelearning field, however, that the practice of service-learning is marked by several models. In any case, with so much practical application being tested, it is clear that "servicelearning has moved beyond the marginalized, co-curricular model of altruism to a sophisticated and integrated pedagogy of promise” (Heffernan, 2001, p. 6).

Whether derived from Campus Compact and its service-learning initiative focused on making students better citizens, or other models developed by “a diverse group of scholars and community partners committed to addressing a range of social concerns” (Heffernan, 2001, p. 6), service-learning has responded to criticism by erecting an elaborate arsenal of practice. Each program has been developed in order to address the "confusion over what experiential education is and how it differs from other approaches” (Conrad \& Hedin, 2003, p. 2).

An example of a specific initiative undertaken to fill in the gap between theory and practice is the Experiential Education Evaluation Project. In addition to carefully defining service-learning, this project more pointedly seeks to "assess the impact of experiential education programs on the psychological, social and intellectual development” of students (Conrad \& Hedin, 2003, p. 2). Typical of this kind of project, a service-learning program will be implemented and carefully assessed with the goal of measuring gains in student achievement levels (Kelshaw, Lazarus, \& Minier, 2009, p. 170).

A broader approach to service-learning falls under the rubric of the engaged campus (Office of Community Service-Learning, 2000, p.2). Abstractly defined, an 
“engaged campus encourages student involvement in activities and organizations that promote university-community partnerships and foster a culture of civic engagement” (Office of Community Service-Learning, 2000, p. 4). However, the concept of the engaged campus remains so nebulous that Campus Compact has provided funding for stakeholders to hold meetings to discuss the concept and derive a "partial consensus" regarding the concept (Office of Community Service-Learning, 2000, p. 4). At the same time that Campus Compact funds such brainstorming programs, it also received funding from organizations such as the Pew Charitable Trust to implement specific programs on campus that will "assist higher education in providing young people with the values, skills and knowledge of active citizenship” (Campus Compact, 2003, p. 1).

A number of programs on campus continue to be informed by the principles laid down by the Wingspread Conference in 1989. Based on Wingspread's publication, The Principles of Good Practice for Combining Service and Learning, the programs thus created are ensured a higher-than-average rate of being sustained, as the Wingspread principles were, specifically, a direct response to the failure of earlier programs like those directed by the National Center for Service Learning, which did not adequately consider how to sustain the program.

Thus, the Wingspread principles “reflect a major concern for creating sound educational programs that could succeed in being institutionalized with the academy” (Mintz \& Hesser, 1996, p. 29). According to Wingspread, a program in service-learning is sustainable if it takes care to establish a rich learning environment and "engages people in responsible and challenging actions for the common good, provides structured opportunities for people to reflect critically on their service experience and articulates 
clear service and learning goals for everyone involved, allows for those with needs to define those needs” (Mintz \& Hesser, 1996, p. 30). A sustainable Wingspread-derived service-learning program will also be noticeable for having programmatic elements that recognize changing circumstances, and the recurrent need for training, monitoring and other forms of supervision (Mintz \& Hesser, 1996, p.29).

Other official programs in service-learning tend to focus on problems experienced in implementation. The Campus Outreach Opportunity Learning program focuses on "the critical elements of thoughtful community service” (Mintz \& Hesser, 1996, p. 31). Programs derived from this document are characterized by orientation and training to build bridges to the community. It is also a preoccupation of this program that the service offered by meaningful to the community, where "meaningful action means that the service being done is necessary and valuable to the community itself” (Mintz \& Hesser, 1996, p. 31).

By contrast, the Faculty Casebook on Community Service Learning is more concerned with safeguarding the academic integrity of service-learning programs. Thus, this casebook asserts that the credits offered for a service-learning course are for the learning that occurs, “not for service” (Mintz \& Hesser, 1996, p. 31). This casebook also provides guidelines to help ensure that the academic rigor is not compromised by the program, that learning goals are set and made clear, and that it "provides educationally sound mechanisms to harvest the community learning” (Mintz \& Hesser, 1996, p. 31). This casebook is in the spirit of efforts by "engaged campus" reformers to ensure faculty participation in community life by encouraging them in public scholarship, or "relating their work to the pressing problems of society” (Boyle \& Hollander, 1999, p. 11). 
Other studies have focused on the degree to which institutional commitment to service-learning impacts the outcome of the service-learning programs (Holland, 1997, p.7). One study found that an institution's failure to define "the role of service in student life” leads to "tentativeness and confusion among faculty and students" with regard to what is expected of them in service-learning (Holland, 1997, p. 36). It seems that on the institutional level, commitment to service-learning continues to lag. California State University-Monterey Bay is "one of the few public universities in the country where service-learning is a graduation requirement” (Rice \& Pollack, 2000, p. 115).

Studies looking more closely into programmatic implementation indicate that several categories of service-learning have developed in response to various criticisms of the field. Pure service-learning occurs when the course has as its “intellectual core” the idea of service. Pure service-learning courses send the students out into the community over the course of a semester and offer ample opportunity in class to reflect on their service "using course content as the basis for their analysis and understanding" (Heffernan, 2001, p. 3). Problem-based service-learning courses, by contrast, focus on a specific community problem, and "students work with community members to understand” that problem (Heffernan, 2001, p. 3). This type of service-learning course "presumes that the students will have some knowledge they can draw upon to make recommendations to the community” (Heffernan, 2001, p. 3). Capstone service-learning courses are usually designed for seniors and ask the student to draw on the "knowledge they have obtained through the course work and combine it with relevant service work in the community” (Heffernan, 2001, p. 3). The purpose of a capstone course is to explore a new topic or synthesize previous and present studies. 
In addition to differences in models of courses, some service-learning courses are discipline-based, while others are solely problem-based. The discipline-based courses are linked to a field of study and "are generally easier to defend intellectually" (Heffernan, 2001, p. 4). In this type of course, the "link between course content and community experience must be very explicit” (Heffernan, 2001, p. 4), even though such explicitness may limit the community experience. Problem-based courses developed due to a concern for the logistical difficulties of full-time courses and involve "limiting the number of times that students have to go out into the community” (Heffernan, 2001, p. 4). In this style of course, the students go out and identify needs, but the risk in this short-cut model is that "there is a danger of promoting the idea of student as experts and community as clients” (Heffernan, 2001, p. 4).

A concern that has developed in the implementation of service-learning courses is this: how does one assess the amount of learning that a student experiences in the servicelearning context? In response to criticism that assessment is weak, the field has imported a number of techniques used in classroom assessment. For example, some servicelearning courses have students keep a journal in which they reflect on what they have done. Another way of assessing a service-learning course is to set very clear goals and to make known that the consequences of failing to reach the goal are serious (Palomba \& Banta, 1999, p. 27). To make sure the commitments a student makes are honored, selfreporting has been employed in which students provide time-sheets or written reports to supervisors (Palomba \& Banta, 1999, p. 236). Evaluation of the program is seen by others to be crucial for giving direction to a service-learning program. 
At the University of Maryland, service-learning students engage in self-reflection in sessions that take place after the service. The emphasis in these sessions is to have students "discover what they have learned from the youngsters they worked with and how they have applied these insights to their service” (Palomba \& Banta, 1999, p. 235). The students in this program also meet regularly with the coordinators of overseeing agencies and "obtain feedback on their work" (Palomba \& Banta, 1999, p. 235). If the service-learning event is short-term, then some practitioners conduct a "post-event gathering of participants during which they share reactions and ideas” (Palomba \& Banta, 1999, p. 235). The post-event occurs some time after the service, under the theory that it sometimes "takes a period of time before the significance of a service-learning event sinks in” (Palomba \& Banta, 1999, p. 235). This delayed meeting also offers students an opportunity to discuss "whether expectations were met and to reflect on the experience" (Palomba \& Banta, 1999, p. 235). One of the most important areas of evaluation is critical thinking, for most service-learning pedagogy believes that such events are ideal to encourage critical thinking in students (Jacoby, 2007, p. 3).

Although Wingspread principles provide the underlying ideas for most servicelearning programs of all models, insisting as they do on reciprocity and mutuality, it has occurred to a number of educators that such an approach to learning would be an ideal locus in which to instill the principles of multicultural education. Thus, a strong flank of service-learning programming deals directly with the fact that, in most cases, the people most students will be serving are from diverse communities, and that diversity, therefore, must be a theoretical concern of service-learning (Mintz \& Hesser, 1996, p. 29; Smith, 2004, p. 52). 
In programs like the You Can Make A Difference Program at the University of Maryland, the service element deals with homeless and runaway youth, but the reflective sessions discuss diversity as it is impacted by power and oppression (Mintz \& Hesser, 1996, p. 29). It is primarily from the diversity side of the service-learning field that a stronger criticism of the term "service” prevails. One educator critiques "service” because, he argues, he "heard service used many times as a self-righteous, vaguely disguised ticket to salvation for upper and middle class people who feel guilty about their access to resources” (Rosenberger, 2000, p. 25). To clarify the term service, it has been distinguished from charity, the latter involving a distance from which one can become patronizing of another, whereas with service “compassion should replace pity and separateness should be transformed into community” (Rosenberger, 2000, p. 25).

Service "involves working alongside people in ways that assist them in defining and helping to fulfill their own needs” (Rosenberger, 2000, p. 26). Service “empowers individuals to work on their own behalf” (Rosenberger, 2000, p. 26). One way in which the diversity of the community can be better understood is to make use of an asset-based community development approach to service-learning. According to this approach, the service-learning participants first undertake a survey or mapping of all the community has to offer. This process "entails discovering and detailing the gifts, abilities and resources of each individual, household, association and institution in the community” (Gugerty \& Swezey, 1996, p. 99). The service-learning program will also help determine "with these stakeholders how to harness these assets to address community needs and problems” (Gugerty \& Swezey, 1996, p. 99). 
Finally, some diversity educators are beginning to see that service-learning can be used as an anti-prejudice tool to reduce stereotypes and to open up communication between diverse populations (Erickson \& O’Connor, 2000). There is nothing new in this claim, as it goes back as far as the theories of Dewey, or Kolb’s learning cycle, both of which argued that one of the positive outcomes of such learning is the erasure of prejudice and stereotyping (Erickson \& O’Connor, 2000, p. 67).

Table 1 below provides a summary of the historical timeline of the development and integration of service-learning into American colleges and universities. 


\section{Table 1}

\section{Service Learning in Higher Education Historical Timeline}

1964 VISTA (Volunteers in Service to America)

Created by President Lyndon B. Johnson as a part of the "War on Poverty."

1970s Senior Service Programs + Peace Corps + VISTA = The ACTION Agency

1973 Domestic Volunteer Service Art of 1973

RSVP, Foster Grandparent Program, and Senior Companion Program become authorized through this act.

1985 Creation of Campus Compact

Formed by the presidents of Brown, Georgetown, and Stanford University to develop the best qualities of American college students and the engaged campus dedication, scholarship, civic engagement, and service.

$1990 \quad$ National and Community Service Act of 1990

Signed by President Bush, the legislation authorizes grants to schools to support service-learning through Serve America and demonstration grants. Learn and Serve America is created.

1992 AmeriCorps National Civilian Community Corps (NCCC) created

Corporation for National and Community Service created

1993 AmeriCorps created; Senior Corps incorporates the three senior-focused programs: Foster Grandparents, Senior Companions. Led by former Peace Corps organizer Harris Wolford.

$1994 \quad$ King Holiday and Service Act of 1994

Congress establishes MLK Day as a national day of service.

20022002 State of the Union Address

After 9/11, President George W. Bush asks all Americans to commit two years or 4,000 hours to volunteer service during their lifetimes.

2006 President's Higher Education Community Service Honor Roll

Initiated by the Corporation for National Service to honor the nation's top college and universities for their commitment to community service, civic engagement, and service-learning.

2007 First Annual AmeriCorps Week

Officially launched in May 2007.

2009 Edward M. Kennedy Serve America Act signed

April 21, 2009: President Barack Obama signs bipartisan law to expand and strengthen national service programs.

2010 Social Innovation Fund launched

Ensures that high-impact nonprofits are able to attract the resources they need to grow and improve the economic, education and health prospects of low-income communities.

2011 Corporation for National Service 5-Year Strategic Plan

The plan details specific objectives, strategies and performance measures, which determine how CNCS will evaluate success over the next five years.

2012 FEMA Corps launched

An innovative new partnership designed to strengthen the nation's ability to respond to and recover from disasters while expanding career opportunities for young people.

2013 Campus Compact attains historical growth

Campus Compact achieves growth from two state Campus Compact offices in 1985 to 32 with five more planned within the next two years. Today 1100 colleges and universities are members of Campus Compact representing and assisting 6 million students.

Adapted in part from History of Service-Learning in Higher Education, National Service Learning Clearinghouse, January 2008. 
Empirical evidence of current service-learning programs does suggest that the experience of service-learning causes students to question previously held beliefs about diverse communities and to amend and change views by allowing "a process that is specifically structured to help students examine frameworks that we use to interpret experience, critically think and reflect” (Crews, 2002, p.41). This process helps students to, “step outside the old and familiar and reframe” questions and conclusions” (Crews, 2002, p. 41).

In sum, a number of models and concerns have begun to inform service-learning practice, all ultimately developed to respond to criticism that service-learning remained vague with regard to the benefits of the practice. In addition to the development of a range of programs, a consensus has emerged on how service-learning positively impacts the learning outcomes of students in several distinct areas, including interpersonal skills, communication skills, affective values, and, finally, and of increasing importance, critical thinking skills (Jacoby, 2007, p. 119).

\section{Service-Learning and Learning Outcomes in Interpersonal Skills, Communication Skills, Affective Values and Critical Thinking}

Ultimately, service-learning will not be able to answer its critics unless it can prove that the practice results in positive learning outcomes for all those involved. As a result, a number of researchers have set out to determine the learning outcomes of service-learning. Positive outcomes have been determined in the areas of interpersonal skills, communication skills, affective values (attitudes, social values, diversity views), and, finally, critical thinking (Jacoby, 2007, p.119). 


\section{Service-learning and interpersonal skills.}

Service-learning, backed by experiential education and the concept of the engaged campus, is being supported by many educators who believe that it provides a student with a more well-rounded education (Angelis, 2003, p. 23; Bringle \& Hatcher, 1996, p. 36; Burr, 2002. p. 96; Campus Compact, 2003, p. 72; Chickering \& Gamson, 1987, p. 91; Eyler \& Giles, et. al., 1997, p.87; Eyler \& Giles, 1999, p.39; Kuh, 1994, p.112; Schwartzmann, 2001, p.95; Jacoby, 2007, p. 119). According to the ideas of experiential education, living itself is described as "learning by doing” (Campus Compact, 2003, p. 12), and service-learning tries to recreate the benefits of this type of learning in formal education. Even more important than simply doing, however, is that the learning truly engages the student, that it is meaningful to the student, and that the student is excited by it (Campus Compact, 2003, p. 12). It is only “a challenging, active, student-centered process that impels students towards opportunities for taking initiative, responsibility and decision-making” (Campus Compact, 2003, p. 17). The most important outcome of such projects is that it offers the student an opportunity to "connect the head with the body, heart, spirit and soul” (Campus Compact, 2003, p. 16).

In addition to providing a student with critical thinking and reflective judgment skills, service-learning has also been found to increase the humanitarian side of students and their "interpersonal and intrapersonal competence” (Kuh, 1994, p. 1). In all these measures, "students who chose to participate in service-learning experiences and those who did not differed significantly” (Eyler \& Giles, et. al., 1997, p. 24).

Service-learning enhances the interpersonal quality of learning because its format revolutionizes the current model of education, which consists of teachers lecturing to students and providing them with facts and data that the student must then "patiently 
receive, memorize, and repeat” (Burr, 2002, p. 14). Although numerous students have mastered the art of filing away information for use in testing, many more are, critics like Freire say, themselves “filed away through lack of creativity, transformation and knowledge in this misguided system” (Burr, 2002, p. 14). Freire argues that the banking model of education that characterizes so many classrooms must be replaced with an experiential-based learning program "which permits the learner to make their way through the unknown, thus learning by becoming aware of and identifying the need for further knowledge” (Burr, 2002, p. 13). Thus, “knowledge emerges only through invention and reinvention, through the restless, impatient, continuing, hopeful inquirer” (Burr, 2002, p. 14). In this context, it is also necessary that the relationships between faculty and student and among students themselves be changed.

Schwartzman argues that the American education system became transmissionist in its orientation because of cultural tendencies, given voice by Emerson, favoring independent thinking of those “detached from the social environment” (Schwartzman, 2001, p. 4). In the Emersonian tradition, the scholar is a "lone thinker," the embodiment of the ideal of the single individual as the core of democracy. This ideal of the solitary thinker has survived in education through methods that foster individualized mastery of learning material and has eschewed cooperative and collaborative learning (Schwartzmann, 2001, p. 4). In addition to creating a weak democracy in which thinkers do not work together to solve problems, this system also creates passive and accepting learners. Technology and education's current obsession with technological means of sharpening the individualization process only deepen the crisis in the banking model of education (Schwartzmann, 2001, p. 3). 
These rhetorical claims regarding the cultural orientation of American education have received scientific backing by cognitive scientists. A century ago, Whitehead complained that too much of the knowledge obtained by students was "inert knowledge," that is, students store up knowledge that is "quite useless to them when they are in new situations” (Eyler \& Giles, 1999, p. 8). Cognitive scientists have confirmed that "students rarely transferred knowledge and principles learned in classroom instruction to new problems” (Eyler \& Giles, 1999, p. 8). Even in situations where the problem-solving exercise is similar to one covered in class, the students often "failed to apply it" (Eyler \& Giles, 1999, p. 8). By contrast, if a student is engaged in "repeated attempts to solve similar problems" in a rich context with encouragement and support, then the student is able to apply what was learned to new situations (Eyler \& Giles, 1999, p. 8). Thus, “decontextualized classroom instruction” is a dead-end for much cognition, and learning is much more effective in "complex contexts" where the students engage in "the active construction of knowledge” (Eyler \& Giles, 1999, p. 8).

Once a break with the classroom has been made and students are propelled into real world situations, students will also find that learning in such contexts turns out to be “more cooperative or communal than individualistic” (Eyler \& Giles, 1999, p. 9). Also, contextual learning involves "using tools rather than pure thought," which also involves interacting with others (Eyler \& Giles, 1999, p. 9). Overall, more learning occurs by “addressing genuine problems in complex settings rather than problems in isolation” (Eyler \& Giles, 1999, p. 9). In the classroom, some educators have tried to move toward this kind of context by creating active learning exercises, including "structured exercises, challenging discussion, team projects and peer critiques” (Chickering \& Gamson, 1987, 
p. 1). Speaking up in class is a hallmark of active learning. In this area, proponents argue that "learning is not a spectator sport" and that "students do not learn much by sitting in classes listening to teachers, memorizing pre-packaged assignments and spitting out answers” (Chickering \& Gamson, 1987, p. 3). Rather, students must "talk about what they are learning, write about it, relate it to past experiences, apply it to their daily lives” (Chickering \& Gamson, 1987, p. 3). In short, students must “make what they are learning part of themselves” (Chickering \& Gamson, 1987, p. 3).

Student-faculty interaction is critical to improved student learning (Smith, 2004, p. 23). Studies have shown that when faculty implement service-learning in their classrooms, it "brings life to the classroom, enhances performance on traditional measures of learning, increases student interest in the subject, teaches new problemsolving skills and makes teaching more enjoyable” (Bringle \& Hatcher, 1996, p. 2). In one study, Markus found that as a result of the introduction of service-learning, classes "had more positive course evaluations" and, in the students, "more positive beliefs and values toward service and community” (Bringle \& Hatcher, 1996, p. 2). This finding is supported by other research that has found that service-learning "has a positive impact on personal, attitudinal, moral, social and cognitive outcomes” (Bringle \& Hatcher, 1996, p. 2). A large part of these gains results from improved faculty-student contact, generating more positive faculty contact outside of class as well (Eyler \& Giles, et. al., 1997, p. 13).

As a result of such findings, service-learning is stressing contact between faculty and student much more. In this, it draws from studies of good practice in higher education overall, which "encourages contacts between students and faculty” (p. 1) where faculty are more able to give prompt feedback to problems, communicate higher 
expectations, and make more use of active learning techniques (Chickering \& Gamson, 1987).

The aforementioned engaged campus concept also seeks to reinforce the interpersonal strengths of students by encouraging students to "make connections among the mission of the institution, their academic pursuits and real world issues beyond the university walls” (Office of Community Service-Learning, 2000, p. 7). Serving Well is a guided programming initiative that seeks to develop lifelong learning in students through service to diverse populations in the university’s community (Angelis, 2003, p. 72). Serving Well seeks to discover the origins of the service orientation in students, going back even to childhood (Angelis, 2003, p. 72). Action research, “a way of generating research about a social system while simultaneously attempting to change that system” (Campus Compact, 2003, p. 1), is another way in which the interpersonal skills of students are expanded. Coined by Lewin, action research operates under the premise that "one of the best ways to understand the world is to try to change it” (Campus Compact, 2003, p. 1).

In trying to understand and change community problems, the service-learning student must interact with a number of individuals from diverse populations. Dewey stated that the "mind is not individual but social, and that learning is a by-product of social activities” (Burr, 2002, p. 4). Integrating service-learning liberates colleges and universities to support the development of interpersonal skills through empowering diversity as an "educational asset to be mined, not a problem to be masked” (Smith, 2004, p. 73). 
Whether service-learning measurably improves the interpersonal skills of students who participate in it remains inconclusive. Previously, "claims for the efficacy of experiential education, provocative and compelling as they are, seem more exhortatory than explanatory, more polemical than empirical” (Moore, 1981, p. 288). Until recently, most reports on service-learning were “journalistic narratives” with little empirical validity (Moore, 1981, p. 288). Studies have revealed that "students who participated in a class in which service-learning was a requirement achieved higher final course grades and (more importantly from the point of view of interpersonal skills) reported greater satisfaction with the course, the instructor, the reading assignment and the grading system” (Berson \& Toukin, 1998, p. 10). One study made use of Tinto's concept that student connection to the institution enhances learning, and support was found for service-learning in that it "seems more vital in terms of student involvement" (Berson \& Tounkin, 1998, p. 11).

\section{Service-Learning and communication skills.}

An additional area where service-learning is showing some signs of educational gains is in communication skills (Carter-Wells, 1996, p. 46; Click, 1996, p. 31; Jacoby, 2007; p. 119, Jones, 1996, p. 28; Smith, 2004, p. 121). Although most of these studies remain tentative or communication skills per se are not sufficiently differentiated from interpersonal skills or values, some findings indicate that service-learning may enhance the ability of students to read, write and orally communicate their thoughts (Jones, 1996. p. 28; Jacoby, 2007, p. 119). Because workplace employers are expecting more graduates to have solid and useful reading skills, college education in general has begun to seek a "better understanding of the role of reading” in learning (Carter-Wells, 1996, p. 
45). Some models believe that readers succeed in a top-down manner, applying their “prior knowledge and linguistic competence” to the text (Carter Wells, 1996, p. 46). Others argue that reading effectiveness derives from breaking the written code in a “bottom-up” manner (Carter-Wells, 1996, p. 46). Still others see that reading becomes effective when there is an ongoing interaction between top-down and bottom-up decoding (Carter-Wells, 1996, p.45; Moore and Parker, 2009, p. 441).

Constructivists assert that in reading, the reader constructs meaning. Servicelearning proponents have picked up the interactive and constructivist idea to argue that students read better and more creatively when they must synthesize and analyze what they have read because they need the knowledge to continue to work effectively in a service context (Carter-Wells, 1996, p. 45; Smith, 2004, p. 121). Also, “reading serves to integrate one's knowledge with that of others . . . to create new knowledge” (CarterWells, 1996, p. 46).

In a similar manner, parallel to but perhaps linked to the service-learning initiative, interest has grown over the last ten years in what is termed "real world writing, or what academicians call nonacademic writing” (Click, 1996, p. 31). In this discourse, researchers are attaching “increased importance ... to the particular contexts within which texts are written, read and used" (Click, 1996, p. 31). Some believe that in real world writing, students improve "not only communication skills but also analytical abilities, critical inquiry and knowledge construction and retention” (Click, 1996, p. 32).

An important element of this initiative in writing is that more educators are taking a "product view of writing” (Click, 1996, p. 31). In this view, professional writing in given contexts consists of creating a product for an office or business context, with the 
“structural features of the text” emphasized (Click, 1996, p. 31). This view of writing contrasts with the expressive theory of writing, or the cognitive theory of writing, both of which emphasize free expression of ideas without consideration of real world context (Click, 1996, p. 32). If writing is embedded in a service-learning project and the writing is assessed based on how well it communicated in context, this will improve the cognitive and expressive elements of writing will improve (Click, 1996, p.37; Kelshaw, Lazarus, \& Minier, 2009, p. 170).

Overall, most of the impetus for college students to read and write better is driven by the demands of employers today, and generally subsumed under the rubric of critical thinking (Jones, 1996, p.7; Moore and Parker, 2009, p. 92). It is no longer enough for students simply to learn facts or data; they must be able to "make informed judgments" on new issues and "to solve complex problems by communicating and working in teams" (Jones, 1996, p. 10). Both by stimulating research experiences in the classroom and through service-learning, this advanced level of communication skills is developed (Jones, 1996, p. 10).

\section{Affective outcomes (attitudes and values) of service-learning.}

Proponents believe that service-learning improves student values and attitudes with regard to citizenship and caring about society at large (Erickson \& O’Connor, 2000; McEwen, 1996; Moore, 1981; O’Grady, 2000). Service-learning, it is argued, will make students better citizens with a sounder and more compassionate understanding of social problems. Moreover, because service-learning often involves service with diverse populations, service-learning has attracted the interest of multicultural educators and is increasingly seen as a method to counteract prejudice or racism (Jacoby, 2007, p. 47). 
One of the strongest arguments supporting service-learning is that it is able to counteract the egocentricity that seems to be the norm in the construction of the self in today's society. The idea that service-learning helps open up the ego to other experiences and people is premised on theories that detail the nature of the ego (Erickson \& O’Connor, 2000, p. 66).

A generation ago, Greenwald proposed a theory of the totalitarian ego, observing that the "inherent tendency of individuals to preserve their current knowledge organizations” (p. 65) is similar in many ways to totalitarian political systems (Erickson \& O’Connor, 2000). The totalitarian ego seeks to “maintain knowledge of self and others in current cognitive schemes” (Erickson \& O’Connor, 2000, p. 67). Accordingly, the self operates by three in-grown cognitive biases, and is first of all egocentric, engaging in what is termed "beneficence, taking responsibility for desired outcomes" (p. 67) and generally engages in “cognitive conservatism” (p. 67) by which it resists any cognitive change (Erickson \& O’Connor, 2000). Taken together, “these habituated informationcontrol strategies preserve our sense of who we are and how we fit with others” (Erickson \& O’Connor, 2000, p. 67). These same strategies “help us define the many different social situations in which we find ourselves” (Erickson \& O’Connor, 2000, p. 67). Overall, it should be emphasized, the operations of the totalitarian are "not a bad thing" and are "part of normal mental health,” but when reinforced by individualistic and isolating learning, this type of ego formation can become blinded to social problems or the plight of others (Erickson \& O’Connor, 2000, p. 67).

Many educators have enlisted service-learning as a direct means to respond to the type of egocentricity in students. Campus Compact, it will be recalled, was instituted to 
counteract the perception that all students were part of what was being termed, in the 1970s and 1980s, the “me generation.” Wingspread’s principles also were constructed to counteract egotism and to ensure that the service provided was authentic and not paternalistic. The most important point in the Wingspread principles, with regard to values, is that the contact in the service be equal and that the student learn as much from the service as the person in the community being served. This idea has been given further theoretical support by Allport's contact theory with regard to contact between diverse cultures. Contact theory "was developed by social psychologists to examine and evaluate the various conditions under which face-to-face contact would promote greater personal and social understanding between members of different ethnic and racial groups” (Erickson \& O’Connor, 2000, p. 63). Contact theory is now being used to “evaluate the potential effectiveness of service learning as an anti-prejudice tool” (Erickson \& O’Connor, p. 2000, 63). Contact theory and the Wingspread principles conflate on a significant issue: contact theory argues that contact can serve to counteract stereotypes only if the parties making contact hold relatively equal power in the relationship (Erickson \& O’Connor, 2000, p. 17).

How such contact actually works is being further explored through context analysis. Derived from symbolic interactionism and the social psychology of Mead and informed by constructivism and cognitive theories of Piaget and Bruner, context analysis locates social events at the “juncture between integrationists’ concept of social behavior and constructivist conceptions of cognitive activity” (Moore, 1981, p. 289). Context analysis undertakes a "detailed description and analysis of speech and movement in a social context” (p. 289) to "uncover the structuring principles of concerted activities” 
(Moore, 1981). Placed together with service-learning, context analysis can explore the intricacies of social situations where contact between diverse people is made, to determine whether the contact is productive (Crews, 2002, p. 41).

Service-learning constructs are carefully detailed because researchers seek to counteract a persistent criticism that, when it comes to contact with communities, most service does not reduce but rather confirms stereotypes. Researchers have worked hard to build a construct that helps to distinguish between ineffective and effective multicultural contact. Christine Sleeter has divided multicultural education into a number of practices. The human relations type of multicultural pedagogy "emphasizes inter-group dynamics and getting along with others while avoiding broader issues of conflict” (O’Grady, 2000, p. 4). In this approach, the similarities between people are emphasized over differences. A number of researchers have found that this approach remains premised on a "unitary view of society” (O’Grady, 2000, p. 4) in which individuals are "united under an umbrella of common interests” (O’Grady, 2000, p. 4). As a result, it lacks critical depth or reform potential. Another approach to multicultural studies, single-group studies, “teaches about specific group’s history and culture” and is exemplified by black studies or Asian studies (O’Grady, 2000, p. 4).

Another approach, the multicultural education approach, actually studies the concepts of discrimination and oppression, but still, to some, "may overlook issues of conflict caused by structural power and oppression” (O’Grady, 2000, p. 4). Although the latter two approaches are based on a pluralistic view of society and regard diversity as “central to understanding individual and group interests” (O’Grady, 2000, p. 4), some think that these approaches, by believing that conflict can be positive and power can be 
ameliorated, do not provide an ultimately realistic idea of power and oppression. As a result, Sleeter supported a final approach to multicultural education, which she termed “social reconstructionist multicultural education” (O’Grady, 2000, p. 4). In this approach, students are taught "directly about oppression, discrimination, social justice, and how to take action against these inequities” (O’Grady, 2000, p. 4).

When placed in the context of this taxonomy of types of multicultural education, it is clear to O’Grady (2000) that most service-learning continues to practice its services in a human relations orientation that fails to adequately consider diversity or the power structures that cause conflict in relations between diverse groups (O’Grady, 2000, p. 9). This is why so many studies find that even as coursework, the political consciousness of students is not being raised, and they are not being made "able to engage in direct experience in political conflict” (O’Grady, 2000, p. 9).

To determine why too few service learning programs provide multicultural consciousness-raising, researchers use models of social and group contact to distinguish effective and ineffective (or even counterproductive) contact (Erickson \& O’Connor, 2000, p. 65). Allport's contact theory is an important theory for this purpose, delineating the conditions under which contact between diverse peoples will lead to positive change in the nature of their relationship (Erickson \& O’Connor, 2000, p. 65). Allport observed that contact is effective for transforming one’s prejudices in a positive way only if the basis of the contact is equality between parties. This observation is an important foundation for positive contact. Moreover, "contact theory posits that the activity in which persons engage should be in pursuit of common goals” (Erickson \& O’Connor, 2000, p. 63). 
Even criticism of contact theory has assisted service-learning in working out the persistent problems involved in contact. For example, contact theory has been criticized for underestimating the power of the ego to persist in stereotyping even after the evidence contradicts the stereotypes. Contact theory believes that when a person encounters some evidence in the behavior or actions of a diverse people that contradicts a preexisting stereotype of that person's ethnic group, the person will "change their preexisting biases" (Erickson \& O’Connor, 2000, p. 65). Others are much less optimistic and have presented research showing that such change is rare, or generally unlikely. Cognitive scientists have found that the ego's mind engages in a defense mechanism they have termed "refencing" where “disconfirming exemplars” are isolated and then ignored to "preserve preexisting ways of thinking” (Erickson \& O’Connor, 2000, p. 65). Such an analysis has forced service-learning researchers to delve more deeply into the nature of the learning process in a contact context.

In a critique of service-learning, O’Grady remarks that "too many writers in the field of service-learning use terms such as 'students' and 'communities' with the implication that they mean all students or all communities when in fact they are referring to white students and middle-class communities” (O’Grady, 2000, p. 11). Moreover, these programs almost uniformly make use of the human relations approach, which, far from breaking down barriers, runs the risk of strengthening stereotypes and "perpetuating a duality between the service and the recipient” (O’Grady, 2000, p. 12).

To further explore the complexities of the contact between diverse groups that so often occurs in service-learning, researchers have also begun to create models that detail the stages of change of mind involved with one’s racial or ethnic identity (McEwen, 
1996, p. 96). Based on Helms’s work, this model posits that at one point, a white person has a purely insulated racial identity that is more or less oblivious to the reality of diversity. Over time, should the person educate him or herself, that person may develop a “nonracist white identity” (McEwen, 1996, p. 78). But even this is a difficult challenge. Some white liberals, for example, intellectually acknowledge diversity and have eschewed all of the racist viewpoints characteristic of white racial identity (regarding primarily the assumed inferiority of persons from diverse groups), but still only “behaviorally work to make persons of color more like whites” (McEwen, 1996, p. 78). In the immersion/emersion phase, the white person begins to seek to understand what it means to be white, though still "the focus is on changing white people rather than on changing others” (McEwen, 1996, p. 78). Only when a person reaches a phase called autonomy does he or she internalize a "positive non-racist white identity” but also "seeks to acknowledge and abolish racial oppression” (McEwen, 1996, p. 78).

On the other side of the equation of diversity, minorities seek to build a sense of their ethnicity in a similarly complex manner. In a model developed by Atkinson, minority people move from accepting their role as minority (conformity) to "questioning one’s belief about self as a minority person (dissonance)” (McEwen, 1996, p. 81). The person then begins to reject the ideas of the dominant society and move toward immersion in one's own race or ethnic group (the resistance and immersion phase). Next, the person begins to "evaluate the strengths and weaknesses of his or her own group (introspection)” and arrives at a synergistic final stage where a sense of pride in one’s own group coupled with an understanding of oppression leads to an activist approach to changing relations between diverse groups (McEwen, 1996, p. 81). 


\section{Critical Thinking and Service-Learning}

Although it is necessary for a service-learning program to be informed by the above models to prevent the experience from leveling out at the ineffective human relations level, some researchers have looked to more revolutionary thinkers to finally give service-learning coupled with multicultural education a potential to change things (Campus Compact, 2003; Conrad \& Hedin, 2003; Eyler \& Giles, 1999; Rosenberger, 2000; Fink, 2003; Smith, 2004; Kelshaw, Lazarus, \& Minier, 2009). Educational theorist Paulo Freire has provided ideas that are the basis of a number of efforts to afford servicelearning real potential for social changes. Freire is important for having defined praxis as consisting of both "reflection and action upon the world in order to transform it" (Rosenberger, 2000, p. 31). Action by itself only leads to activism, which Freire defined as "acting without thinking critically about the consequences” (p.31) and which is therefore "often thoughtless and unmindful of both the process and the result of the action” (Rosenberger, 2000, p. 31). Thus, in reform, "reflection and action must be hand in hand so that action, if it is to be thoughtful, is preceded and followed by reflection" (Rosenberger, 2000, p. 31).

Combining action and reflection is one aspect of programming that defines reformed service-learning (Jacoby, 2007, p. 99). Freire also defines dialogue as a process of naming the world conducted between subjects "who are open to seeing the world through the eyes of others and who grant others the right of naming the world" (Rosenberger, 2000, p. 37). This idea, which for Freire is based on love and faith in people, is a fundamental building block of much new service-learning. Freire also emphasized that all education should be concerned with problem-posing. According to 
his definition of the process, faculty and students engage generative, universal themes, that must be unearthed from constructs that in social life "prevent people from seeing reality clearly and critically” (Rosenberger, 2000, p. 39). These constructs “act as blinders not only to current reality but also to new possibilities” (Rosenberger, 2000, p. 39). Only when one has unearthed the reality lying under these "limit-situations" (p. 39) and deconstructed them can truly critical dialogue occur (Rosenberger, 2000).

In service-learning, problem-posing, as Freire has constructed it, has been used to give students consciences about social issues. Teachers re-present the universe as a problem to students, and students must then seek to "solve” (p. 39) that problem, often through dramatization and role playing, asking questions, or engaging in service-learning encounters. For critical thinking to be developed in service-learning, problem-posing must be engaged in, and problem-posing is distinguished from problem-solving in that problem-posing is "the process of unveiling and problematizing reality” (Rosenberger, 2000, p. 39). If service-learning does not analyze the oppressive conditions of reality, it risks merely reproducing power and merely flattering those with privilege through their “helping” (p. 33) of the less privileged (Rosenberger, 2000). This creates (parallel to what was also termed by Sleeter as the human relations approach to multiculturalism) what Freire calls “false generosity” (Rosenberger, 2000, p. 33). Only if service-learning includes a process of conscientization, that is, the process by which service-learners “achieve a deepening awareness both of the sociocultural reality that shapes their lives and of their capacity to transform that reality” (Rosenberger, 2000, p. 36), will servicelearning come clear of the persistent criticisms against its effectiveness in social situations. 
In essence, then, Freire and Jacoby argue that only by encouraging in its participants serious critical thinking about social realities can service-learning become effective (Rosenberger, 2000, p. 36; Jacoby, 2007, p. 119). Critical thinking, in this way, has become a linchpin of effective service-learning. Indeed, the process of discovery of new perspectives is believed by most service-learning theorists to be the result of action and reflection as mapped out by Freire and Jacoby (Rosenberger, 2000, p. 36; Jacoby, 2007, p. 119). When a service-learning program places students in a context where they must confront their prejudices and also many of their assumptions about reality and the world, the resulting "cognitive dissonance” (p. 17) that is created is believed to serve as a catalyst to critical thinking (Eyler \& Giles, 1999).

In the context of service-learning, reflection and critical thinking are linked. According to Kolb’s model of the learning cycle, reflection involves deriving a hypothesis from a problem, testing it, and reflecting on the results (Campus Compact, 2003). A number of service-learning programs use critical thinking. In most best practice templates of service-learning, reflection is believed to be the "vital link between service and learning” (Eyler \& Giles, 1999, p. 3). Having established the balance between action and reflection as a best practice, it was also found that too many service-learning models “do not fit this balanced model” (Eyler \& Giles, 1999, p. 3). Studies have shown that when programs are able to balance action and reflection, the service-learning program has a positive effect on student learning (Conrad \& Hedin, 2003, p. 17).

Using a problem-solving inventory (though Freire distinguishes between problemposing and problem-solving, many in the literature do not), the study found that "students in programs combining experience and reflection (showed) substantial increases in 
complexity of thinking and in ability to empathize with others” (Conrad \& Hedin, 2003, p. 26). In $80 \%$ of such experiential programs, students were shown to have made positive gains in "attitudes towards adults and others with whom they worked, and felt more positively toward being active in the community” (Conrad \& Hedin, 2003, p. 26). Community-situated programs were also found to have a stronger impact on the student's moral reasoning. Overall, however, it is evident that the best practices of service-learning call for critical thinking as a vital element of all programs, if they are to counteract criticisms as to their effectiveness.

\section{Research regarding critical thinking and service-learning outcomes.}

Service-learning emerged in its modern form in the 1970s and 1980s in response to a concern among educators that college students were becoming too materialistic and uncritical of the world around them (Ehrlich, 1996; Eyler \& Giles, 1999; Huba \& Freed, 2000; Myers-Lipton, 1994; Palomba \& Banta, 1999, Smith, 2004). Many of the ideas that fed the early definition of service-learning in its modern form were derived from a body of thought that falls under the rubric of critical education theory. This way of thinking derives from Gramsci, Freire, and the Frankfurt school, and places education in the context of its socioeconomic reality to find a way for students to become critical thinkers about society (Myers-Lipton, 1994, p. 60).

With Robert Coles calling for service-learning to enhance the moral character of students and with Dewey reemerging at that time, a number of voices were raised to change the passive values of liberal arts college life and replace them with a pedagogy that encouraged critical thinking about life and society (Ehrlich, 1996, p. xii). At that same time, educators argued that all learning today or in the economy of the future should 
be lifelong learning, and that learning how to solve problems and critically analyze realities is important to this form of learning (Huba \& Freed, 2000, p. 222; Smith, 2004, p. 51; Jacoby, 2007, p. 47).

The kind of thinking that students were required to do in classrooms, primarily entailing repeating data and pre-solved problems, must be replaced by engaging in "true tests” (Huba \& Freed, 2000, p. 221). Only when a student becomes involved in a true test is the student forced to make judgments and apply knowledge. Moreover, "true tests" are also "ill-defined" or "ill-structured" problems, which are, contrary to the neat "problems" so often presented to students in math classes, real-life problems requiring student engagement in complex thinking on many levels (Huba \& Freed, 2000, p. 222). With these problems that are also called unstructured problems, it is believed that in the struggle to “identify, frame, resolve and perhaps redress unstructured problems” (Eyler \& Giles, 1999, p. 117), students engage in “advanced cognitive development” (Eyler \& Giles, 1999, p. 117) and thus develop more critical thinking skills. Indeed, the best service-learning programs are those that engage unstructured problems. Even when students in service-learning first experience confusion by a social context and are “confused by the difficulty of solving social problems, they are discovering something essential about the nature of these issues” (Eyler \& Giles, 1999, p. 103). This ethos corresponds to the idea expounded by Hannah Arendt that for a citizen to function democratically, he or she must have some tolerance for uncertainty and yet still be able to make decisions (Eyler \& Giles, 1999, p. 103).

For all of this discussion about the importance of critical thinking in servicelearning, however, “critical thinking as a consequence of service-learning has not been 
well studied” (p. 103) though there is some evidence that students do better when thinking on a problem if the problem is similar to one encountered in a service-learning context (Eyler \& Giles, 1999).

In formulating best practices for service-learning, many educators found that service-learning can indeed promote critical thinking in positive ways (Eyler \& Giles, 1999, p. 102; Smith, 2004, p. 27; Crews, 2002, p. 66; Jacoby, 2007, p. 99). As a result, service-learning and critical thinking have become identified. Indeed, studies often rate the effectiveness of a particular service-learning program on how it impacts the critical thinking skills of the students involved. One test found that service-learning did positively effect "all four survey measures of critical thinking” (p. 121) meaning that the program discussed was deemed effective (Eyler \& Giles, 1999). A number of instruments have been developed to determine whether gains in critical thinking occur as the result of an intervention. The Watson Glaser Critical Thinking appraisal, which goes back to the 1930s, scored critical thinking on the basis of whether students could make inferences, recognize assumptions in arguments, make deductions, interpret data, and analyze and evaluate arguments (Palomba \& Banta, 1999, p. 252). Peter Facione created the Holistic Critical Thinking Scoring Rubric in 1994 to measure whether students showed any gains in their analysis and evaluation skills as the result of an intervention (Palomba \& Banta, 1999, p. 252). The California Critical Thinking Dispositions Inventory "assesses seven factors that are exhibited by those who possess dispositions to be critical thinkers” (Palomba \& Banta, 1999, p. 255). The factors included on this scale include “truth-seeking, open-mindedness, systemic thinkers, inquisitiveness and maturity” (Palomba \& Banta, 1999, p. 255). Many more researchers have eschewed 
commercial instruments to use their own approaches to assessing critical thinking. Jones has explored the nature of critical thinking, including insightful thinking, wherein one sees the possibilities in things; rational thinking, which entails logical thinking; and evaluative thinking, which leads students to "take positions about things and to examine feelings and values” (Palomba \& Banta, 1999, p. 252).

The question still remains, however: what is critical thinking? Dewey, once again, perhaps began the process of defining the term by outlining the phases of what he termed reflective thought (Giles \& Eyler, 1994, p. 80). These phases were suggestion (or considering different courses of action), intellectualization (which entails defining the problem and raising questions), creating the hypothesis (or "the development of a guiding idea based on observation and previous knowledge”) (Giles \& Eyler, 1994 p. 80), and testing the hypothesis in action (either verifying or disproving it). In 1990, the American Philosophical Association reported on the consensus of what critical thinking is, taken from a survey of 46 leading figures in many different fields of study (Palomba \& Banta, 1999, p. 250). This survey characterized critical thinking as "the process of purposeful, self-regulatory judgment, the cognitive engine that drives problem-solving and decisionmaking” (Palomba \& Banta, 1999, p. 251). According to this view, critical thinking entails “interpretation, analysis, inference, evaluation and explanation” as these five skills are the key to making judgments "about what to believe or do" (Palomba \& Banta, 1999, p. 251). By this measure, truly critical thinkers are able to "explain their interpretations and analyze their own inferences," and they can also "monitor, correct and improve the process of coming to a judgment” (Palomba \& Banta, 1999, p. 251). These same skills 
are shown to be important to any problem-solving experience (Dougherty \& Fantaske, 1996, p. 76; Smith, 2004, p. 45; Jacoby, 2007. p. 3; Moore \& Parker, 2009, p. 393).

Other theorists have placed critical thinking in the context of thinking at large, in a manner derived ultimately from Piaget. Piaget defined adult thinking in terms of what he termed “formal operational thinking, that is, the ability to handle abstraction" (Eyler \& Giles, 1999, p. 109). Others have looked at the "post-formal nuances” in adult thinking, finding that adults not only think abstractly, but also "think critically about ill-structured problems” (Eyler \& Giles, 1999, p. 109).

Younger has constructed a model of thinking that starts with simple stages and broad dualistic thinking, and progresses to a series of relativities, as Perry calls them, in which the student "begins to accept the presence and legitimacy of multiple points of view and of the interdeterminacy of truth” (Eyler \& Giles, 1999, p. 109). In King and Kitchener's model of reflective judgment, the self also moves from simple to critical thinking. Here too, in this model students ultimately mature to the point where they can handle ill-structured problems and frame them in complex ways (Eyler \& Giles, 1999, p. 110). In the beginning, students in service-learning cannot even recognize the illstructured nature of a social problem and deal with the problem in dualistic ways or in ways that rely on the authority of preexisting explanations (Eyler \& Giles, 1999, p. 110). As students mature, they come to see that problems have situational variables and that knowledge is contextual. Students then move on to relativism, where "knowledge is constructed by comparing evidence on different sides of an issue or across contexts" (Eyler \& Giles, 1999, p. 111). At the end of this process, students “are comfortable with the reality that social problem solving is not something that can be accomplished once 
and for all and that human decisions are always subject to error and revision” (Eyler \& Giles, 1999, p. 110).

As a result of these models, researchers are now able to evaluate the effectiveness of service-learning based on the type of critical thinking that it encourages. A survey found that students were aware that they were thinking differently in service-learning as compared to classrooms and that "the understanding attained through service-learning enhanced what they learned from books and lectures” (Eyler \& Giles, 1999, p. 69). Another survey reports that students believed they learned more and understood more through service-learning (Eyler \& Giles, 1999, p. 70). A study of student critical thinking skills in general found that "participation in well-integrated and highly-reflective servicelearning classes was a predictor of increased complexity in analysis of both causes and solutions of social problems” (Eyler \& Giles, 1999, p. 75). Moreover, “students who participated in highly integrated service-learning were also more likely to develop a realistic personal strategy from community problem-solving” (Eyler \& Giles, 1999, p. 77). These students were also much more aware of the complexities involved in coming to a judgment on a complex social issue (Eyler \& Giles, 1999, p. 72).

Overall, a study of students who took service-learning classes, when compared to a control group who did not, reported that the service-learning students learned more and were motivated to work harder. These students also liked service-learning and routinely exhibited enthusiasm about this way of studying (Eyler \& Giles, 1999, p. 72). Although this excitement is often dismissed as mere feel-good pablum, cognitive research confirms that students learn more when they are excited by and interested in what they are learning — thus feeling good means learning more (Eyler \& Giles, 1999, p. 72). More 
important from the point of view of critical thinking, the students in the service-learning course showed a "deeper understanding of subject matter" and a better understanding of the complexity of the social issue (Eyler \& Giles, 1999, p. 81).

Still, some educators, particularly in this time of accountability in education, demand more proof that service-learning improves not only the quality of learning, but also the extent that achievement will increase. A survey has noted that most students enjoyed service-learning more than regular classwork, but whether they actually learned more is more difficult to measure. A key study found that among students who took a service-learning course, their critical thinking skills remained "relatively stable” over the course of the semester (Eyler \& Giles, 1999, p. 124). Moreover, when compared to the control group of students in a regular classroom, the differential in critical thinking skills gains was so minimal that it was indicated that "service learning in and of itself was not a predictor of change in critical thinking” (Eyler \& Giles, 1999, p. 124). Most students in the study, in fact, did not show any significant gains in their critical thinking skills over the course of the semester. One-third of the students did, however, show some "upward movement” (Eyler \& Giles, 1999, p. 124). When community service was central to the day-to-day operation of the course, this upward movement was more noticeable.

Reflective activities in the service-learning course were also believed to contribute to this positive movement in critical thinking.

Although Eyler \& Giles (1999) express disappointment that critical thinking did not improve as a result of service-learning, they also suggest that it may be that the students being surveyed did not understand enough about what "critical thinking” is to answer the question properly. Also, some changes in thinking processes were noted, 
especially in the arts and sciences-related service-learning courses. For instance, it was found that "those who participated in the service experience were more likely to see problems as systemic and that changing policy was a better approach than targeting individuals, and believe that improving social justice should be a priority for society, to be able to see things from the perspective of others, and to be open to new ideas" (Eyler \& Giles, et. al., 1997, p. 35), all of which are elements of mind leading to critical thinking.

Thus, although a semester's worth of service-learning did not improve the ultimate critical thinking skills of the students involved, the semester's work did effect their "reported ability to identify social issues and changed their openness to new ideas" (Eyler \& Giles, 1999, p. 126), both of which are positive outcomes of service-learning when considering students' minds. These students also began to engage more in structured reflection, saw the consequences of actions more, and were able to identify new social issues. Taken altogether and using the broader framework of King and Kitchener’s theory of reflective judgment, Eyler and Giles (1999) assert that "students who are in service-learning classes where service and learning are well integrated through classroom focus and reflection are more likely to show an increase in their level of critical thinking demonstrated in problem analysis” (Eyler \& Giles, 1999, p. 126).

As to whether the increase in critical thinking leads to better grades, only a few studies indicate that service-learning may be improving education, and such studies generally have only mixed results. Markus conducted a study of students in political science and found that students in the service-learning sections of the course "received significantly better grades than those assigned to non-service sections” (Eyler \& Giles, 
1999, p. 62). Another study "found that the students in a child development course who elected the service option had higher course grades” (Eyler \& Giles, 1999, p. 62). These reports appear encouraging, even if at present the higher grades measured derive from extra credit gains and not from test performance scores seemingly mandated as proof of positive outcomes in the current accountability climate in education. The overall trend of the literature on service-learning vis-à-vis critical thinking and academic outcomes is that this mode of learning is a highly promising, viable model for improved pedagogy in the future.

\section{Critical thinking and Gender}

One study conducted in a southwestern university concluded that female participants performed greater than males in an assessment of critical thinking skills (Srinivasan and Crooks, 2005, p. 36). There are other researchers who maintain that women and men have cognitive strengths that are unique to each gender. Halpern et. al (2007) examined critical thinking skills emphasizing quantitative tasks that use visual symbols, mental manipulation of objects, writing and memory for objects, people, words and activities (Halpern, et. al. 2007, p. 36). This research concluded that males demonstrated significant gains in the skills of mental manipulation of objects and quantitative tasks that use visual symbols. The same study concluded that women demonstrated significant gains in the areas writing and memory for objects, people, words and activities.

Leach and Good examined male and female differences in the 5 critical thinking dimensions of analyses, induction, deduction, evaluation, and inference based on the colleges of Arts and Sciences, Business and Technology, Clinical and Rehabilitative 
Health Sciences, Continuing Studies, Education, Nursing and Public Health and gender among a population of seniors (Leach and Good, 2011, pp. 104-105). The results of the study concluded that there was no statistically significant differences between male and female performance in the 5 critical thinking dimensions of analyses and induction. The same study concluded that male students performed significantly higher than female students in the area of deduction, evaluation, and inference. In an examination of gender and reflective judgment consisting of 17 studies, King and Kitchner concluded that in 6 of the studies, males demonstrated greater performance than females and the rest demonstrated no difference (King \& Kitchner, p. 62, 1994). Caplan and Caplan assert that most of the claims about critical thinking and gender are not sufficiently supported by sound research (Caplan \& Caplan, 2008, p. 136). They contend that many of the tools that are used to examine critical thinking and gender in the literature are not equipped to conclude most of the claims about gender and critical thinking. The overall trend in the literature is that the issue of critical thinking and gender is a continuing subject of debate among researchers.

\section{Conclusion}

This literature review has examined the implementation of service-learning in college campuses today (Angelis, 2003; Bringle \& Hatcher, 1996; Burr, 2002; Campus Compact, 2003; Chickering \& Gamson, 1987; Eyler \& Giles, et. al., 1997; Eyler \& Giles, 1999; Kuh, 1994; Schwartzmann; 2001, Fink, 2003; Smith, 2004; Kelshaw, Lazarus, \& Minier, 2009; Smith, 2004; Jacoby; 2007). Built on a solid history of service and a body of educational theory going back to Dewey, service-learning has made great gains in education in recent years, for a number of reasons related to achievement levels and 
social responsibility of American college students. Because service-learning has developed in converging streams of research, there are at present a number of different praxes of service-learning, and a best practices literature is gradually being developed to ensure that service-learning be defined as a distinct field bounded by clear scientific principles with regard to practice (Erickson \& O’Connor, 2000; McEwen, 1996; Moore, 1981; O’Grady, 2000). Especially problematic in the development of service-learning was constructing models of the thought process and actual learning that is said to occur in the process of community service.

Experiential education theory was the basis of the development of servicelearning, but support was also provided by critical education theorists such as Paolo Freire, who argue in favor of a more engaged and responsible type of learning to replace the banking model of education. Critical thinking has emerged as a centerpiece of theories of service-learning primarily to counteract early and persistent criticism that service-learning amounts to educational fluff (Ehrlich, 1996; Eyler \& Giles, 1999; Huba \& Freed, 2000; Myers-Lipton, 1994; Palomba \& Banta, 1999; Crews, 2002; Fink, 2003; Smith, 2004; Jacoby, 2007; Kelshaw, Lazarus, \& Minier, 2009). If according to Jacoby and others service-learning includes action and reflection and develops critical thinking, then the contact made between students and service partners will steer clear of paternalistic do-gooding and actually help the student learn about society in a critical manner. A number of studies are showing that service-learning counteracts prejudice, raises consciousness, and improves the critical thinking skills of students. Thus, servicelearning has arrived at a state of theoretical and practical maturity, poised to roll out a new generation of programs that, abiding by best practices, will actually help not only 
students improve their critical thinking skills but also as people in the communities solve their social problems.

In sum, this literature review suggests that it is important to provide examination of gains in critical thinking outcomes do students make in courses that include servicelearning.

\section{Research Questions}

This study examined the effect of service-learning on development of critical thinking among a sample of undergraduate students participating in service-learning courses at the Campus Compact-affiliated, public four-year, non-historically black university in Maryland with fewer than 5,000 students addressed the following research questions:

(RQ1) Does participation in general education courses that include servicelearning result in gains in critical thinking by students in the courses?

(RQ2) Are there significant differences in critical thinking outcomes for male students as compared to female students in general education courses that include service-learning? 


\section{Chapter Three}

\section{Method}

\section{Participants}

The purpose of this study was to examine the effect of service-learning on development of critical thinking among a sample of undergraduate students participating in service-learning courses at the Campus Compact-affiliated, public four-year, nonhistorically black university in Maryland with fewer than 5,000 students. Out of a population of 66 general education courses with 1,584 students, this study is made up of a sample of five general education courses with 120 students. General education courses such as English 101 and Introduction to Higher Education that include service-learning were chosen to enhance the generalizability of the results by preventing the specialization of field or major from interfering with a general assessment of critical thinking changes associated with service-learning. These courses were required courses of all students regardless of their major or field of specialization. More specifically, to ensure that the classes across the institution have similar characteristics, the sample included only classes matched across the institution based on:

1. gender,

2. course descriptions,

3. proportion of class enrollment (i.e., Freshman, Sophomore, Junior, Senior),

4. class enrollment count, and

5. distribution of majors.

A matching strategy was employed based upon prioritization of a variable’s likely influence or salience in the context of this study. Although it is acknowledged that the 
study is conducted using intact classes, the highest priority in matching was focused on the gender composition of the classes. Subsequent class level matching was implemented to the fullest extent feasible and practicable in descending order of concurrence using the four other variables listed directly above. Additionally, no class with fewer than 10 students of either gender was included in the sample.

\section{Setting}

The following table (See Table 2) provides a comprehensive listing of all colleges and universities in Maryland that are members of Campus Compact and a disaggregated summary of non-historically black, four year public colleges and universities in Maryland with a student enrollment of no more than 5,000. Frostburg State University is the only college or university that meets all of the criteria for selecting a setting for this study. General inquiries were made to the institution selected for this sample revealed that they have developed service-learning programs through the agency of Campus Compact. There is a paucity of research examining the effects of service-learning on critical thinking in small-sized public Campus Compact affiliated universities in rural settings that are non-historically black. This university has three colleges and a student enrollment of 4,600 undergraduate and 700 graduate students. 
Table 2 MD Public 4 Year Student enrollment MD Non-HBC

Campus Compact Members College/University $\leq 5,000$

Anne Anundel Community College

Carroll Community College

Chesapeake College

College of Notre Dame of Maryland

Coppin State University

Frostburg State University

Goucher College

Harford Community College

Johns Hopkins University

Loyola College in Maryland

Maryland Institute, College of Art

McDaniel College

Montgomery College

Mount St. Mary's University

Prince George's Community College

Stevenson University

Towson University

University of Baltimore

University of Maryland-Baltimore

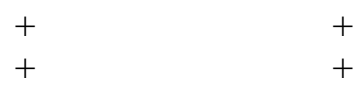

University of Maryland Baltimore County +

University of Maryland-College Park +

Washington College

Wor-Wic Community College

Data tabulated from:

Maryland Campus Compact Organizational Membership List 2012

Maryland Higher Educational Commission Institutional Profiles 2012

This selection provides robust data to analyze the types of potential gains in critical thinking outcomes that students who participate in general education courses that include service-learning demonstrate over time (i.e., the treatment effect). This selection process also provides essential data that were analyzed for significant differences in critical thinking outcomes for male as compared to female in these general education courses that include service-learning. The sample was made up of 120 students and five courses. Statistical power analysis was used to determine the sample size for this study (Cohen, J. 1992, pp. 155-159). The statistical power analysis was performed to 
determine the appropriate sample size at the .80 power, the accepted statistical standard criteria, (Cohen, 1992, p. 155 Erdfelder, Lang \& Buchner, 2007, p. 172). The total sample size of at least 120 students is appropriate for this study design and statistical analysis (Cohen, 1992, p. 155, Erdfelder, Lang, \& Buchner, 2007, p.172).

Table 3 provides a summary of A Priori Power Analysis for Gender Effect, Pre-Post Testing Effect, Scales Effect, Gender X Pre-Post Interaction,and Gender X Scales Interaction at the .80 statistical power threshold to determine the total sample size required for this study given those parameters. The purpose of Gender X Scales Interaction analysis is to determine if statistically significant gender differences emerge in the CCTST scales of analysis, evaluation, inference, deduction, induction and if the gender effect varies across the different scales. For the repeated measures, a conservative nonsphericity correction of .5 was assumed as well as a .5 correlation among the repeated measures.

\section{Table 3}

\section{A Priori Power Analyses to determine sample size at the $\mathbf{. 8 0}$ threshold statistical power}

1) A Priori Power Analysis for Gender Effect - At a statistical power threshold of .8 and medium effect size, a total sample of 98 is required. Critical F $(1,96)=3.94$. Actual a priori power equal .808. Noncentrality parameter equal 8.17.

2) A Priori Power Analysis for Pre - Post Testing Effect - At a statistical power threshold of .8 and medium effect size, a total sample of 34 is required. Critical $F(1,32)=4.15$. Actual a priori power equal .807. Noncentrality parameter equal 8.50.

3) A Priori Power Analysis for Scales Effect - At a statistical power threshold of .8 and medium effect size, a total sample of 30 is required. Critical $F(2.5,70)=2.90$. Actual a priori power equal .816. Noncentrality parameter equal 11.25.

4) A Priori Power Analysis for Gender X Pre-Post Interaction - At a statistical power threshold of .8 and medium effect size, a total sample of 34 is required. Critical $F(1,32)$ $=4.15$. Actual a priori power equal .807 . Noncentrality parameter equal 8.50 . 5) A Priori Power Analysis for Gender X Scales Interaction - At a statistical power threshold of .8 and medium effect size, a total sample of 30 is required. Critical F (2.5, $70)=2.90$. Actual a priori power equal .816. Noncentrality parameter equal 11.25. 


\section{Measures}

The study employed the California Test of Critical Thinking Skills 2000. The instrument was used during two phases of data collection. Phase one consisted of direct administration of the CCTST as a pre-test. Phase two consisted of direct administration to the same students of the California Test of Critical Thinking Skills as a post-test near the end of the course.

The California Critical Thinking Skills Test (CCTST) was chosen because of its clear delineation of subscales within critical thinking (analysis, evaluation, inference, and deductive and inductive reasoning), because it has strong validity and reliability, and because it requires only forty-five minutes to administer. The focus on critical thinking as a measure of learning is consistent with the emphasis placed on critical thinking in current studies of service-learning. A number of instruments have been developed to measure critical thinking outcomes. The Watson Glaser Critical Thinking appraisal, initially seen in the literature in the 1930's, scored critical thinking on the basis of whether students could make inferences, recognize assumptions in arguments, make deductions, and interpret and analyze data (Palomba \& Banta, 1999, p. 255). The Holistic Critical Thinking Scoring Rubric, created by Peter Facione in 1994, emphasized analysis and evaluation skills as the key elements of critical thinking. The California Critical Thinking Dispositions Inventory focused on seven factors involved in critical thinking, including truth-seeking, open-mindedness, inquisitiveness and maturity (Palomba \& Banta, 1999, p. 255).

The clarity and reported validity and reliability of the California Critical Thinking Skills Test recommended its use. The use of such a scale provides a reliable and valid 
measure of improvements in critical thinking in general education courses that include service-learning. The CCTST is an instrument developed by Peter Facione of Insight Assessment, Inc. This instrument was used to determine whether service-learning measurably impacts critical thinking.

The CCTST consists of 34 questions and is a 45- minute timed assessment of Critical Thinking that measures the influence of five critical thinking outcomes and an overall outcome: Inductive Reasoning, Deductive Reasoning, Analysis, Inference, Evaluation, and Total Score. It is a highly researched instrument with sound documentation regarding its validity and reliability relative to the purpose, population/subjects, and applications of this dissertation.

CCTST content validity has been well established. Content validity examines the extent to which the items included in the instrument represent the conceptual breadth of the concept measured (Sullivan, 2001, p. 26) or expressed in another manner, how the sampling of the characteristic demonstrates the behaviors of the entire domain for that characteristic (Walsh \& Betz, 2001, p. 87). The CCTST purports to measure critical thinking. In this instrument’s development, the American Philosophical Association Delphi consensus conceptualization of critical thinking was utilized. That is, each item was aligned for relationship to Delphi Critical Thinking conceptualization (CCTST Test Manual, 2008). The selected items represent the five critical thinking skills of interpretation, analysis, evaluation, explanation, and inference. The items were constructed from this universe without bias for sex role and social class stereotyping. Relatedly, face validity or the examination of the logical or apparent connection between the measurement and the variable (Sullivan, 2001, p. 27) has been documented via 
faculty committee adoption of the instrument for research purposes, including dissertations (CCTST Test Manual, 2008) as well.

Construct validity refers to the correspondence of the instrument's measurements to a theoretical framework (Sullivan, 2001, p. 26). Construct validity is the operationalized representation of theoretical constructs that can be further explored by examining hypothesized relationships among variables (Walsh \& Betz, 2001, p. 90). For the CCTST, the specific construct definition is the "extent to which the CCTST measures the Delphi conceptualization of critical thinking” (CCTST Test Manual, 2008). To confirm the construct validity of the CCTST, critical thinking improvement has been measured by the CCTST after participation in a critical thinking course. Pre- to postCCTST scores were shown to significantly improve after college students completed general education critical thinking courses (Kennison, 2006, p. 19). Similarly, Bartlett and Cox found CCTST improvement results by (Bartlett \& Cox, 2002, p. 44) as a result of critical thinking academic emphases. Further, previous research has confirmed CCTST pre- and post-testing to be a viable means of assessing changes in students' critical thinking skills (Soukop, 1999, p. 36). Finally, the construct validity of the CCTST has been supported by factor analytic results (Khalli \& Hosselu, 2003, p. 14).

Criterion validity demonstrates a correlation between the measurement instrument and some other criterion or measure that is generally sought (Sullivan, 2001, p. 27). Significant positive correlations have been demonstrated between the CCTST and a variety of other standardized instruments. For example, CCTST has been shown to be positively related to SAT (verbal and math) (Facione, 1990) and GRE scores (analytic, verbal, and quantitative) as well as the Watson-Glaser Critical Thinking Appraisal 
(CCTST Test Manual, 2008). Supportive of the criterion validity of the CCTST, age and general number of academic units earned were not significantly related to this assessment instrument (Facione, 1990, p. 7). Finally, using linear regression, the predictive value of the total CCTST score for first-year professional grade point average and cumulative professional grade point average was evaluated. It was found that the CCTST was significantly predicative of both these academic achievement measures (Adams, Leader, Jain, \& Lawrence, 2008, p. 36).

CCTST’s reliability has generally been evaluated by examining the device’s internal consistency. Internal consistency, or the premise that the items are homogeneous in measuring a single construct (LaFountain \& Bartos, 2002, p. 17) as assessed by the Kuder-Richardson 20 (KR-20), has been routinely reported and is typically above .70 (Kennison, 2006, p. 14; Khalli \& Hosselu, 2003, p. 27). The Kuder-Richardson is the comparable statistic to Cronbach’s alpha for dichotomously evaluated measurements. The CCTST has demonstrated a parallel forms equivalency between forms A and B of .69 using the KR-20 statistical procedure (Facione, \& Facione, 1992, p. 2).

Although the author found no direct test-retest quantitative reliability study figures for the CCTST per se, related measures have shown sound retest reliabilities of .77 on the Triage Decision-Making Inventory (TDMI) (Cone, 2000, p. 48) and .79 on the California Critical Thinking Dispositions Inventory (Yeh, 1996, p. 32). In general, research on adults has shown that critical thinking skills are relatively stable attributes/factors within proscribed timeframes unless influenced by courses and/or pedagogies, (Ku, 2009, p. 19). 


\section{Procedures}

Phase one consisted of direct administration of the CCTST as a pre-test to students in five individual general education courses offered at the selected university based upon Campus Compact Coordinator identification of these courses through completion of the Campus Compact Questionnaire (See Appendix B) and Campus Compact Coordinator contact with the instructor. Courses were identified in which the instructor was willing to allow the researcher to contact him to schedule a visit to the classes to conduct pre and post assessment using the CCTST.

As a result of on-site visit with the Campus Compact Coordinator, individual contact was made with course instructors by telephone to arrange dates, times, and locations that the researcher can directly administer the CCTST pre-test.

Each instrument was coded to indicate the institution, course and student that the pre-test was administered to, with pre-test administrations occurring approximately 6 weeks prior to the end of the semester, prior to the beginning of the service-learning experience. Each student completed an assessment administered by the researcher on campus in the classroom. This ensured test security by providing individual oversight and implementation of the CCTST protocol, in the test administration manual, by the researcher of all test materials at all times. The students were informed that their participation is entirely voluntary and that they may have ceased participation at any time in the process, if so desired. (Appendix C).

Phase two consisted of direct post-test administration of the CCTST to students who participated in the direct pre-test administration. Post-test administration utilized the coded identification for each institution and each student who completed the pre-test 
administration. The researcher directly administered the CCTST post-test to ensure test security essential to this instrument. This phase was completed during the last week of the end of the course. An Institutional Review Board (IRB) request for exempt status for this study was submitted prior to commencing the pre-test as this study asked questions of adults that are non-controversial, non-dangerous and within the traditional practices of courses. Participating course instructors were provided a copy of the abstract of the study upon its conclusion.

\section{Design}

This intervention and associational study (Frankel \& Wallen, 2000, p. 17) used a pre-and post-assessment approach to answer the research questions. An associational investigation is defined by Frankel and Wallen (2000) as "research in which a researcher looks for relationships having predictive and/or explanatory power” (p. 17). Further, Frankel and Wallen (2000) define intervention studies as those where "a particular method or instrument is expected to influence one or more outcomes” (p. 17). In this study, the treatment was the service-learning experience and the measurement of the extent to which it may influence critical thinking outcomes. Frankel and Wallen (2000) suggest that to "find out whether one thing will have an effect on something else, researchers need to conduct some form of intervention study” (p. 17). The effects and relationships were determined through Analysis of Variance and correlational statistical techniques within the context of a causal-comparative or “ex post facto" methodology. Frankel and Wallen (2000, p. 662) define causal comparative research as "research to determine the cause for, or consequences of, existing differences in groups of individuals, also referred to as ex post facto research. Data were collected from pre- and post-direct 
administration of the CCTST to students involved in five general education courses with 120 students that had service-learning integrated into the course at a Campus Compact member, non-historically black, public four-year college or university with a student enrollment of less than 5,000, Maryland, during the spring of 2013.

\section{Data Analysis}

Data were analyzed using two factorial analyses of variance to determine main effects, and interactions:

1) (ANOVA 1) examined the research questions in the context of the scales (skill).

2) (ANOVA 2) addressed the two research questions in the framework of the overall score. Table 4, below provides a summary of the main effects and interactions that were analyzed to address research (RQ1) and (RQ2).

Table 4 - Effects Analyzed by this Dissertation

Gender Effect

CCTST Pre-Post testing

Scales (Skill) Effect

Gender X Pre-Post 2 way Interaction

Gender X Scales 2 way Interaction

Scales X Pre-Post 2 way Interaction

Gender X Scales X Pre-Post testing 3 way Interaction
Effect Studied in:

ANOVA 1, ANOVA 2

ANOVA 1, ANOVA 2

ANOVA 1

ANOVA 1, ANOVA 2

ANOVA 1

ANOVA 1

ANOVA 1

Note: Also included are t-tests to examine which skill(s) differ by gender. An Analysis of Covariance was also completed on the overall score to examine post-test gender differences when the pretest was used as the control variable.

Statistical analyses were run with the Statistical Program for the Social Sciences (SPSS, version 22). The results were disaggregated to examine potential differential measures of critical thinking outcomes in male as compared to female students, CCTST 
Pre-Post Testing, Scales Effect, Gender X Pre-Post Interaction, Gender X Scales Interaction, Scales X Pre-Post Interaction, and Gender X Scales X Pre-Post testing 3 way interaction. Results are considered statistically significant at the .05 alpha level. Post hoc analysis of significant omnibus ANOVA main and interaction effects was implemented as appropriate.

An explanation of the data sources and analysis that were used for each question follows:

Research Question 1 (RQ1):

1. Does participation in general education courses that include service-learning result in gains in critical thinking by students in the courses?

This question was answered by analyzing the aggregate data from the CCTST direct pre and post test administrations. The CCTST mean scores in each of the subscale critical thinking outcome areas of Inductive Reasoning, Deductive Reasoning, Analysis, Inference, Evaluation, and Total Score are reported in Chapter Four. The mean of the net difference in the scores, subscale scores, and total scores between the pre and post CCTST administrations are also reported. Research Question 1 (RQ1) relates to gains and was examined by the Pre-Post test repeated measures main effect. Potential interaction of this factor with the other variables (factors) was also be examined by this ANOVA statistical analysis using the Statistical Program for the Social Sciences (SPSS).

Research Question 2 (RQ2):

2. Are there significant differences in critical thinking outcomes for male students as compared to female students in general education courses that include servicelearning? 
This question was answered by analyzing the aggregate data from the CCTST direct pre-and post-test administrations. An Analysis of Covariance was also completed on the overall score to examine posttest gender differences when the pretest was used as the control variable. The CCTST mean scores for male as compared to female students in each of the CCTST subscales are also reported in chapter four. Question 2 (RQ2) relates to CCTST differences by demographic factors and was addressed by examining the main effect of gender. 


\section{Chapter Four: Results}

This chapter presents the results of this study which examined the effect of service-learning on development of critical thinking among a sample of undergraduate students participating in service-learning courses at the Campus Compact-affiliated, public four-year, non-historically black university in Maryland with fewer than 5,000 students. The sample studied was students pursuing an undergraduate degree at the public four-year, Maryland university affiliated with Campus Compact and included five general education courses with 120 students participating in this study.

\section{Participants}

Data were collected from pre- and post-direct administration of the CCTST to students involved in 5 general education courses with 120 students that had servicelearning integrated into the course at a Campus Compact member, non-historically black, public four-year college or university with a student enrollment of less than 5,000, Maryland, during the spring of 2013. Phase one consisted of direct administration of the CCTST as a pre-test to students in five general education courses offered at the selected university based upon Campus Compact Coordinator identification of these courses through completion of the Campus Compact Questionnaire (See Appendix B) and Campus Compact Coordinator contact with the instructor.

Phase two consisted of direct post-test administration of the CCTST to students who participated in the direct pre-test administration. Post-test administration utilized coded identification for each student who completed the pre-test administration. The results were disaggregated to examine potential differential measures of critical thinking outcomes in male as compared to female students, CCTST Pre-Post Testing, Scales 
Effect, Gender X Pre-Post Interaction, Gender X Scales Interaction, Scales X Pre-Post Interaction, and Gender X Scales X Pre-Post testing 3 way interaction (Table 3). Results are considered statistically significant at the .05 alpha level. Post hoc analysis of significant omnibus ANOVA main and interaction effects was performed as appropriate.

The organization of Chapter 4 presents the findings for the analyses including the skills followed by the analyses premised on the overall score. In each instance the descriptive statistics are followed by the presentation of the inferential statistical results. The Greenhouse-Geisser ANOVA correction was implemented to adjust the degrees of freedom in the ANOVA to assure a more accurate significance (p) value (Baugley, 2004).

\section{Findings}

Research Question 1 (RQ1):

1. Does participation in general education courses that include service-learning result in gains in critical thinking by students in the courses?

Research Question 1 (RQ1) was answered by analyzing the aggregate data from the CCTST direct pre- and post-test administrations. Raw scores were translated (recoded) according to the requirement that performance assessments of CCTST "scale scores be made with a cut score table that corresponds to the form of the test that was administered” (Facione, 2008, p. 30). Table 5 reports the CCTST mean scores in each of the subscale critical thinking outcome areas of Inductive Reasoning, Deductive Reasoning, Analysis, Inference, Evaluation, and Total Score. 
Table 5

\section{CCTST Mean Scores sub-scale Critical thinking outcome areas}

(by pre-post and gender)

Recoded for Differing Scales - Descriptive Statistics

\begin{tabular}{|c|c|c|c|c|}
\hline Skill (Pre/Post) & GENDER & Mean & Std. Deviation & $\mathrm{N}$ \\
\hline \multirow[t]{3}{*}{ Analysis Pre-Recoded } & Female & 1.7759 & .75028 & 58 \\
\hline & Male & 1.9839 & .75730 & 62 \\
\hline & Total & 1.8833 & .75796 & 120 \\
\hline \multirow{3}{*}{$\begin{array}{l}\text { Inference Pre- } \\
\text { Recoded }\end{array}$} & Female & 1.4483 & .53549 & 58 \\
\hline & Male & 1.6452 & .54613 & 62 \\
\hline & Total & 1.5500 & .54772 & 120 \\
\hline \multirow{3}{*}{$\begin{array}{l}\text { Deduction Pre- } \\
\text { Recoded }\end{array}$} & Female & 1.3448 & .51476 & 58 \\
\hline & Male & 1.5323 & .53463 & 62 \\
\hline & Total & 1.4417 & .53130 & 120 \\
\hline \multirow{3}{*}{$\begin{array}{l}\text { Induction Pre- } \\
\text { Recoded }\end{array}$} & Female & 1.6724 & .57393 & 58 \\
\hline & Male & 1.8226 & .55881 & 62 \\
\hline & Total & 1.7500 & .56880 & 120 \\
\hline \multirow{3}{*}{$\begin{array}{l}\text { Evaluation Pre- } \\
\text { Recoded }\end{array}$} & Female & 1.4828 & .53775 & 58 \\
\hline & Male & 1.5645 & .59011 & 62 \\
\hline & Total & 1.5250 & .56453 & 120 \\
\hline \multirow{3}{*}{$\begin{array}{l}\text { Analysis Post- } \\
\text { Recoded }\end{array}$} & Female & 1.8621 & .84704 & 58 \\
\hline & Male & 2.1935 & .74303 & 62 \\
\hline & Total & 2.0333 & .80891 & 120 \\
\hline \multirow{3}{*}{$\begin{array}{l}\text { Inference Post- } \\
\text { Recoded }\end{array}$} & Female & 1.6034 & .52781 & 58 \\
\hline & Male & 1.6613 & .47713 & 62 \\
\hline & Total & 1.6333 & .50098 & 120 \\
\hline \multirow{3}{*}{$\begin{array}{l}\text { Deduction Post- } \\
\text { Recoded }\end{array}$} & Female & 1.4483 & .53549 & 58 \\
\hline & Male & 1.5645 & .49987 & 62 \\
\hline & Total & 1.5083 & .51850 & 120 \\
\hline \multirow{3}{*}{$\begin{array}{l}\text { Induction Post- } \\
\text { Recoded }\end{array}$} & Female & 1.8276 & .46408 & 58 \\
\hline & Male & 1.9194 & .58108 & 62 \\
\hline & Total & 1.8750 & .52760 & 120 \\
\hline \multirow{3}{*}{$\begin{array}{l}\text { Evaluation Post- } \\
\text { Recoded }\end{array}$} & Female & $1.5,000$ & .56970 & 58 \\
\hline & Male & 1.5323 & .53463 & 62 \\
\hline & Total & 1.5167 & .54976 & 120 \\
\hline
\end{tabular}


Question 1 (RQ1) relates to gains and was examined by the Pre-Post test repeated measures main effect. Table 6 reports the mean of the net difference in the scores, subscale scores, and total scores between the pre and post CCTST administrations.

Table 6

Recoded Pre-Post - Descriptive Statistics

\begin{tabular}{|l|r|r|r|r|r|}
\hline Pre/Post & N & Minimum & Maximum & Mean & Std. Deviation \\
\hline Mean Pre & 120 & 1.00 & 2.60 & 1.6300 & .44507 \\
Mean Post & 120 & 1.00 & 2.60 & 1.7133 & .43132 \\
Valid N (listwise) & 120 & & & & \\
\hline
\end{tabular}

Question 1 (RQ1) relates to gains and was examined by the Pre-Post test repeated measures main effect. Potential interaction of this factor with the other variables (factors) was examined by this ANOVA statistical analysis using the Statistical Program for the Social Sciences (SPSS). Table 7 reports the mean of the net difference in the scores, subscale scores, and total scores for gender across the pre and post CCTST administrations.

Table 7

Descriptive Statistics-Recoded

\begin{tabular}{|ll|r|r|r|r|r|}
\hline GENDER & $\mathrm{N}$ & Minimum & Maximum & Mean & Std. Deviation \\
\hline Female & Mean & 58 & 1.10 & 2.20 & 1.5966 & .31676 \\
& Valid N (listwise) & 58 & & & & \\
\hline Male & Mean & 62 & 1.00 & 2.30 & 1.7419 & .36554 \\
& Valid N (listwise) & 62 & & & & \\
\hline
\end{tabular}


Potential interaction of gains examined by the Pre-Post test repeated measures main effect were examined by ANOVA (ANOVA 1) statistical analysis using the Statistical Program for the Social Sciences (SPSS, version 22). The answer to Research Question (Q1), as shown in Table 8 Pre-Post test repeated measures shows a trend toward significance, in that the mean recoded post-test aggregated score is higher than its pre-test counterpart. The Greenhouse-Geisser procedure adjusts the ANOVA degrees of freedom test in order to determine a more accurate significance probability level (Field, 2005, p. 114). The sphericity repeated measures assumption is that the all the variances of the differences are equal; that is, that the variances between all possible pairs of the groups are equal (Field, 2005, p. 13). 


\section{Table 8}

ANOVA 1-Tests of Within-Subjects Effects - Recoded for Differing Scales 2 (Pre-Post) by 5 (Type of Skill) by $\mathbf{2}$ (Gender) ANOVA with repeated measures on the first two factors Measure: MEASURE 1

\begin{tabular}{|c|c|c|c|c|c|c|}
\hline Source & & \begin{tabular}{|c} 
Type \\
III Sum \\
of \\
Squares
\end{tabular} & $\mathrm{df}$ & $\begin{array}{l}\text { Mean } \\
\text { Square }\end{array}$ & F & Sig. \\
\hline $\begin{array}{l}\text { PREPOST } \\
\text { Trend Toward Significance }\end{array}$ & $\begin{array}{l}\text { Sphericity Assumed } \\
\text { Greenhouse- } \\
\text { Geisser }\end{array}$ & $\begin{array}{l}2.114 \\
\underline{\mathbf{2 . 1 1 4}} \\
\end{array}$ & $\begin{array}{r}1 \\
\underline{\mathbf{1 . 0 0 0}} \\
\end{array}$ & $\begin{array}{l}2.114 \\
\underline{\mathbf{2 . 1 1 4}} \\
\end{array}$ & $\begin{array}{l}2.990 \\
\underline{\mathbf{2 . 9 9 0}} \\
\end{array}$ & $\begin{array}{r}.086 \\
. \mathbf{0 8 6} \\
\end{array}$ \\
\hline $\begin{array}{l}\text { PREPOST * GENDER } \\
\text { Not Significant }\end{array}$ & $\begin{array}{l}\text { Sphericity Assumed } \\
\text { Greenhouse- } \\
\text { Geisser }\end{array}$ & $\begin{array}{l}.114 \\
.114 \\
\end{array}$ & $\begin{array}{r}1 \\
\mathbf{1 . 0 0 0} \\
\end{array}$ & $\begin{array}{l}.114 \\
.114 \\
\end{array}$ & $\begin{array}{l}.161 \\
.161 \\
\end{array}$ & $\begin{array}{r}.689 \\
. \mathbf{6 8 9} \\
\end{array}$ \\
\hline Error(PREPOST) & $\begin{array}{l}\text { Sphericity Assumed } \\
\text { Greenhouse- } \\
\text { Geisser } \\
\end{array}$ & $\begin{array}{l}83.403 \\
83.403\end{array}$ & $\begin{array}{r}118 \\
118.000\end{array}$ & $\begin{array}{l}.707 \\
.707\end{array}$ & & \\
\hline $\begin{array}{l}\text { SKILL } \\
\text { Highly Significant }\end{array}$ & $\begin{array}{l}\text { Sphericity Assumed } \\
\text { Greenhouse- } \\
\text { Geisser }\end{array}$ & $\begin{array}{l}40.353 \\
\underline{\mathbf{4 0 . 3 5 3}} \\
\end{array}$ & $\begin{array}{r}4 \\
3.175 \\
\end{array}$ & $\begin{array}{l}10.088 \\
\mathbf{1 2 . 7 0 9} \\
\end{array}$ & \begin{tabular}{|l|}
49.920 \\
49.920 \\
\end{tabular} & $\begin{array}{l}.000 \\
.000 \\
\end{array}$ \\
\hline $\begin{array}{l}\text { SKILL * GENDER } \\
\text { Not Significant } \\
\end{array}$ & $\begin{array}{l}\text { Sphericity Assumed } \\
\text { Greenhouse- } \\
\text { Geisser }\end{array}$ & $\begin{array}{l}1.453 \\
\underline{\mathbf{1 . 4 5 3}}\end{array}$ & $\begin{array}{r}4 \\
3.175 \\
\end{array}$ & $\begin{array}{r}.363 \\
.458 \\
\end{array}$ & $\begin{array}{l}1.797 \\
\underline{\mathbf{1 . 7 9 7}} \\
\end{array}$ & $\begin{array}{l}.128 \\
.144 \\
\end{array}$ \\
\hline Error(SKILL) & $\begin{array}{l}\text { Sphericity Assumed } \\
\text { Greenhouse- } \\
\text { Geisser }\end{array}$ & $\begin{array}{l}95.386 \\
95.386\end{array}$ & $\begin{array}{r}472 \\
374.662\end{array}$ & $\begin{array}{l}.202 \\
.255\end{array}$ & & \\
\hline $\begin{array}{l}\text { PREPOST * SKILL } \\
\text { Not Significant }\end{array}$ & $\begin{array}{l}\text { Sphericity Assumed } \\
\text { Greenhouse- } \\
\text { Geisser }\end{array}$ & $\begin{array}{l}.868 \\
. \mathbf{8 6 8} \\
\end{array}$ & $\underline{3.265}$ & $\begin{array}{l}.217 \\
.266 \\
\end{array}$ & $\begin{array}{l}1.057 \\
\underline{\mathbf{1 . 0 5 7}} \\
\end{array}$ & $\begin{array}{l}.377 \\
.371 \\
\end{array}$ \\
\hline $\begin{array}{l}\text { PREPOST * SKILL * GENDER } \\
\text { Significant Not }\end{array}$ & $\begin{array}{l}\text { Sphericity Assumed } \\
\text { Greenhouse- } \\
\text { Geisser }\end{array}$ & .568 & $\begin{array}{r}4 \\
3.265 \\
\end{array}$ & $\begin{array}{l}.142 \\
.174 \\
\end{array}$ & $\begin{array}{l}.692 \\
.692 \\
\end{array}$ & $\begin{array}{l}.598 \\
.569 \\
\end{array}$ \\
\hline Error(PREPOST*SKILL) & $\begin{array}{l}\text { Sphericity Assumed } \\
\text { Greenhouse- } \\
\text { Geisser }\end{array}$ & $\begin{array}{l}96.940 \\
96.940\end{array}$ & $\begin{array}{r}472 \\
385.211\end{array}$ & $\begin{array}{l}.205 \\
.252\end{array}$ & & \\
\hline
\end{tabular}

.Notes: The sphericity repeated measures assumption is that the all the variances of the differences are equal; that is, that the variances between all possible pairs of the groups are equal. The Greenhouse-Geisser procedure adjusts the ANOVA degrees of freedom test in order to determine a more accurate significance probability level. 
Research Question 2 (RQ2)

2. Are there significant differences in critical thinking outcomes for male students as compared to female students in general education courses that include service-learning? This question was answered by analyzing the aggregate data from the CCTST direct pre-and post-test administrations. Question 2 (RQ2) relates to CCTST differences by demographic factors and was addressed by examining the main effect of gender (Table 8). Gender X Pre-Post Interaction, Gender X Scales Interaction, and Gender X Pre-Post X Scales Interaction analyses were conducted to examine whether there were neither significant two way interactions or a significant three way significant interaction. As shown in Table 9, there were neither significant two way interactions or a significant three way significant interaction.

Table 9

ANOVA 1 Tests of Between-Subjects Effects-Recoded for Differing Scales

\begin{tabular}{|c|c|c|c|c|c|}
\hline Source & $\begin{array}{l}\text { Type III } \\
\text { Sum of } \\
\text { Squares }\end{array}$ & $\mathrm{df}$ & $\begin{array}{l}\text { Mean } \\
\text { Square }\end{array}$ & $\mathrm{F}$ & Sig. \\
\hline Intercept & 3339.934 & 1 & 3339.934 & 2841.415 & .000 \\
\hline GENDER - Statistically Significant & $\underline{6.334}$ & $\underline{1}$ & $\underline{6.334}$ & $\underline{5.388}$ & .022 \\
\hline Error & 138.703 & 118 & 1.175 & & \\
\hline
\end{tabular}

Transformed Variable: Average Statistically Significant

The analysis demonstrates that males performed significantly better than females (collapsed across all skills and pre-post conditions). There are no significant interactions. Table 10 presents post hoc analysis of significant omnibus analysis of variance (ANOVA) main effect that was necessary to determine which specific CCTST skills differ from each other. 
Table 10

Post-hoc Analysis (after the Omnibus ANOVA 1)

Pairwise Comparisons - RECODED FOR DIFFERING SCALES

Measure: MEASURE 1

\begin{tabular}{|c|c|c|c|c|c|c|}
\hline \multirow[b]{2}{*}{ (I) SKILL } & \multirow[b]{2}{*}{ (J) SKILL } & \multirow{2}{*}{$\begin{array}{l}\text { Mean Difference } \\
(\mathrm{I}-\mathrm{J})\end{array}$} & \multirow[b]{2}{*}{ Std. Error } & \multirow[b]{2}{*}{ Sig. ${ }^{b}$} & \multicolumn{2}{|c|}{$\begin{array}{c}\text { 95\% Confidence Interval for } \\
\text { Difference }^{\mathrm{b}}\end{array}$} \\
\hline & & & & & Lower Bound & Upper Bound \\
\hline $1-$ & 2 & $.364^{*}$ & .047 & .000 & .230 & .499 \\
\hline \multirow[t]{3}{*}{ Analysis } & 3 & $.481^{\star}$ & .045 & .000 & .352 & .611 \\
\hline & 4 & $.143^{\star}$ & .043 & .011 & .021 & .266 \\
\hline & 5 & $.434^{*}$ & .052 & .000 & .284 & .584 \\
\hline $2-$ & 1 & $-.364^{*}$ & .047 & .000 & -.499 & -.230 \\
\hline \multirow[t]{3}{*}{ Inference } & 3 & $.117^{\star}$ & .028 & .001 & .036 & .198 \\
\hline & 4 & $-.221^{\star}$ & .032 & .000 & -.314 & -.128 \\
\hline & 5 & .070 & .043 & 1.000 & -.054 & .193 \\
\hline 3- & 1 & $-.481^{\star}$ & .045 & .000 & -.611 & -.352 \\
\hline \multirow[t]{3}{*}{ Deduction } & 2 & $-.117^{\star}$ & .028 & .001 & -.198 & -.036 \\
\hline & 4 & $-.338^{\star}$ & .038 & .000 & -.446 & -.230 \\
\hline & 5 & -.047 & .040 & 1.000 & -.161 & .066 \\
\hline \multirow{4}{*}{$\begin{array}{l}\text { 4- } \\
\text { Induction }\end{array}$} & 1 & $-.143^{*}$ & .043 & .011 & -.266 & -.021 \\
\hline & 2 & $.221^{\star}$ & .032 & .000 & .128 & .314 \\
\hline & 3 & $.338^{\star}$ & .038 & .000 & .230 & .446 \\
\hline & 5 & $.291^{*}$ & .036 & .000 & .188 & .393 \\
\hline \multirow{4}{*}{$\begin{array}{l}\text { 5- } \\
\text { Evaluation }\end{array}$} & 1 & $-.434^{*}$ & .052 & .000 & -.584 & -.284 \\
\hline & 2 & -.070 & .043 & 1.000 & -.193 & .054 \\
\hline & 3 & .047 & .040 & 1.000 & -.066 & .161 \\
\hline & 4 & $-.291^{\star}$ & .036 & .000 & -.393 & -.188 \\
\hline
\end{tabular}

Based on estimated marginal means

*. The mean difference is significant at the .05 level.

b. Adjustment for multiple comparisons: Bonferroni.

The post hoc analysis of significant omnibus analysis of variance (ANOVA) main skills (scales) effects were used to perform statistical analysis to determine statistically 
significant differences for scales of analysis, inference, deduction, induction, and evaluation is reported in Table 11.

Table 11

Means of Skills - Descriptive StatisticsRECODED FOR DIFFERING SCALES

\begin{tabular}{|l|r|r|r|r|r|}
\hline \multicolumn{1}{|c|}{ Skill } & $\mathrm{N}$ & Minimum & Maximum & \multicolumn{1}{c|}{ Mean } & Std. Deviation \\
\hline 1-Analysis & 120 & 1.00 & 3.00 & 1.9583 & .60315 \\
2-Inference & 120 & 1.00 & 2.50 & 1.5917 & .41497 \\
3-Deduction & 120 & 1.00 & 2.50 & 1.4750 & .36582 \\
4-Induction & 120 & 1.00 & 2.50 & 1.8125 & .42040 \\
5-Evaluation & 120 & 1.00 & 2.50 & 1.5208 & .41198 \\
Valid N (listwise) & 120 & & & & \\
\hline
\end{tabular}

The post hoc analysis of significant omnibus analysis of variance (ANOVA) main skills (scales) are ranked from high to low as presented in Table 12:

Table 12

Significant Omnibus ANOVA skills (scales) Ranked High to Low
1. Analysis
2. Induction
3. Inference
4. Evaluation
5. Deduction

The means of skills by gender (recoded for differing scales) are graphically presented in Table 13. The resultant data were used to explore which skills might differ by gender through T-tests for Gender differences by Skill. 
Table 13

Means of Skills by Gender- Descriptive Statistics-

RECODED FOR DIFFERING SCALES 1=Female 2= Male

\begin{tabular}{|lll|r|r|r|}
\hline Skill & Gender & $\mathrm{N}$ & \multicolumn{1}{c|}{ Mean } & Std. Deviation & Std. Error Mean \\
\hline Analysis & 1 & 58 & 1.8190 & .63314 & .08313 \\
& 2 & 62 & 2.0887 & .54716 & .06949 \\
\hline Inference & 1 & 58 & 1.5259 & .40200 & .05278 \\
& 2 & 62 & 1.6532 & .42066 & .05342 \\
\hline Deduction & 1 & 58 & 1.3966 & .34740 & .04562 \\
& 2 & 62 & 1.5484 & .37009 & .04700 \\
\hline Induction & 1 & 58 & 1.7500 & .37755 & .04957 \\
& 2 & 62 & 1.8710 & .45209 & .05742 \\
\hline Evaluation & 1 & 58 & 1.4914 & .40275 & .05288 \\
& 2 & 62 & 1.5484 & .42184 & .05357 \\
\hline
\end{tabular}

To explore which skills might differ by gender, t-tests were undertaken. The ttests (Table 14) show that the gender effect, favoring males, is primarily associated with the analysis and deduction skills.

Table 14

T-tests for Gender Differences by Skill

\begin{tabular}{|c|c|c|c|c|}
\hline \multirow[b]{2}{*}{ Skill } & \multicolumn{4}{|c|}{ t-test for Equality of Means } \\
\hline & $\mathrm{t}$ & df & $\begin{array}{l}\text { Sig. (2- } \\
\text { tailed) }\end{array}$ & $\begin{array}{c}\text { Mean } \\
\text { Difference }\end{array}$ \\
\hline \multicolumn{5}{|l|}{ Analysis } \\
\hline SIGNIFICANT & -2.490 & 112.951 & .014 & -.26974 \\
\hline \multicolumn{5}{|l|}{ Inference } \\
\hline & -1.696 & 117.944 & .093 & -.12736 \\
\hline \multicolumn{5}{|l|}{ Deduction } \\
\hline SIGNIFICANT & -2.318 & 117.998 & .022 & -.15184 \\
\hline \multicolumn{5}{|l|}{ Induction } \\
\hline & -1.595 & 116.539 & .113 & -.12097 \\
\hline \multicolumn{5}{|l|}{ Evaluation } \\
\hline & -.757 & 117.948 & .450 & -.05701 \\
\hline
\end{tabular}


An ANOVA on the overall score was conducted. This ANOVA, on the overall score, showed similar results. The overall ANOVA is a 2 (Pre- post) by 2 (Gender) with repeated measures on the prepost. For the overall the actual scores were used, since there was not a scaling differential consideration (that existed when analyzing the ANOVA with the individual skills as a variable). The CCTST mean scores for male as compared to female students in each of the CCTST subscales are reported in Table 15.

\section{Table 15}

\section{Descriptive Statistics for the OVERALL ANOVA}

\section{Gender- Descriptive Statistics}

\begin{tabular}{|ll|r|r|r|r|r|r|}
\hline \multirow{2}{*}{ GENDER } & \multicolumn{1}{|c|}{$\mathrm{N}$} & \multicolumn{1}{c|}{ Minimum } & \multicolumn{1}{c|}{ Maximum } & \multicolumn{2}{|c|}{ Mean } & \multicolumn{1}{c|}{ Std. Deviation } \\
\cline { 2 - 7 } & \multicolumn{1}{|c|}{ Statistic } & \multicolumn{1}{c|}{ Statistic } & \multicolumn{1}{c|}{ Statistic } & \multicolumn{1}{c|}{ Statistic } & \multicolumn{1}{c|}{ Std. Error } & \multicolumn{1}{c|}{ Statistic } \\
\hline \multirow{2}{*}{ Female } & Mean OVERALL & 58 & 6.00 & 18.50 & 12.3103 & .42987 & 3.27380 \\
& Valid N (listwise) & 58 & & & & & \\
\hline \multirow{2}{*}{ Male } & Mean OVERALL & 62 & 5.00 & 20.00 & 13.7177 & .49370 & 3.88737 \\
& Valid N (listwise) & 62 & & & & & \\
\hline
\end{tabular}

(Not recoded overall)

Pre-post differences on the overall score and descriptive statistics for the overall ANOVA are presented in Table 16.

\section{Table 16}

Pre-Post- Descriptive Statistics for the overall ANOVA

\begin{tabular}{|ll|r|r|r|}
\hline Pre/post & GENDER & \multicolumn{1}{c|}{ Mean } & Std. Deviation & $\mathrm{N}$ \\
\hline Pre & Female & 11.8448 & 4.71207 & 58 \\
& Male & 13.3065 & 4.82340 & 62 \\
& Total & 12.6000 & 4.80616 & 120 \\
\hline Post & Female & 12.7759 & 4.41704 & 58 \\
& Male & 14.1290 & 4.91396 & 62 \\
& Total & 13.4750 & 4.71002 & 120 \\
\hline
\end{tabular}

(Not recoded overall) 
A second ANOVA was conducted to explore a significant prepost effect on the overall score. As a result of ANOVA 2 (Table 17), there is not a significant prepost effect on the overall score, but the trend is in the expected direction.

\section{Table 17}

ANOVA 2 Significance of Prepost Effect on Overall Score

\begin{tabular}{|c|c|c|c|c|c|c|}
\hline Source & & $\begin{array}{c}\text { Type III Sum of } \\
\text { Squares }\end{array}$ & df & Mean Square & $\mathrm{F}$ & Sig. \\
\hline PREPOST & Sphericity Assumed & 46.076 & 1 & 46.076 & 2.466 & .119 \\
\hline \multirow[t]{3}{*}{ Not Significant } & Greenhouse-Geisser & $\underline{46.076}$ & $\underline{1.000}$ & $\underline{46.076}$ & $\underline{2.466}$ & .119 \\
\hline & Huynh-Feldt & 46.076 & 1.000 & 46.076 & 2.466 & .119 \\
\hline & Lower-bound & 46.076 & 1.000 & 46.076 & 2.466 & .119 \\
\hline PREPOST * GENDER & Sphericity Assumed & .176 & 1 & .176 & .009 & .923 \\
\hline \multirow[t]{3}{*}{$\underline{\text { Not Significant }}$} & Greenhouse-Geisser & .176 & 1.000 & .176 & .009 & .923 \\
\hline & Huynh-Feldt & .176 & 1.000 & .176 & .009 & .923 \\
\hline & Lower-bound & .176 & 1.000 & .176 & .009 & .923 \\
\hline \multirow[t]{4}{*}{ Error(PREPOST) } & Sphericity Assumed & 2204.386 & 118 & 18.681 & & \\
\hline & Greenhouse-Geisser & 2204.386 & 118.000 & 18.681 & & \\
\hline & Huynh-Feldt & 2204.386 & 118.000 & 18.681 & & \\
\hline & Lower-bound & 2204.386 & 118.000 & 18.681 & & \\
\hline
\end{tabular}


Tests of Between-Subjects Effects were conducted to allow for interpretation of overall score means were conducted consistent with the CCTST Recommended Performance Assessment Overall Scores protocol (Facione, 2008, p. 29). The overall Tests of the BetweenSubjects Effects (Gender) results are presented in Table 18. On the overall measure, males performed significantly better than females as well.

TABLE 18

ANOVA 2 OVERALL - Tests of Between-Subjects Effects

\begin{tabular}{|l|r|r|r|r|r|}
\hline Source & $\begin{array}{r}\text { Type III Sum of } \\
\text { Squares }\end{array}$ & df & Mean Square & \multicolumn{1}{|c|}{ F } & Sig. \\
\hline Intercept & 40602.514 & 1 & 40602.514 & 1562.935 & .000 \\
GENDER - & $\underline{\mathbf{1 1 8 . 7 1 4}}$ & $\underline{1}$ & $\underline{\mathbf{1 1 8 . 7 1 4}}$ & $\underline{\mathbf{4 . 5 7 0}}$ & $\underline{\mathbf{0 3 5}}$ \\
\hline SIGNIFICANT. & 3065.449 & 118 & 25.978 & & \\
Error & & & & \\
\hline
\end{tabular}

While the gender effect was significant (Table 18), an analysis of covariance (ANCOVA) (see Table 19) was also performed to determine if the post-test scores (i.e., dependent variable) would demonstrate this difference, when adjusted for pretest differences. The results below indicate that the gender differences on the posttest are not significant when the pretest differences are used as covariates to adjust the posttest scores. 
TABLE 19

ANCOVA OVERALL - Analysis of Pretest as Covariate on Post Test Scores

\begin{tabular}{|c|c|c|c|c|c|}
\hline Source & SS & df & MS & $\mathbf{F}$ & Sig \\
\hline Adjusted means & 36.64 & 1 & 36.64 & 1.7 & 0.195 \\
\hline Adjusted error & 2516.01 & 117 & 21.5 & & \\
\hline Adjusted Total & 2552.65 & 118 & & & \\
\hline
\end{tabular}

The observed posttest means were 12.7759 and $\mathbf{1 4 . 1 2 9 0}$ for the females and males, respectively. In order, the adjusted means for the females and males were 12.897 and 14.0157. The test for homogeneity of regressions was not significant $F(1,116) p=$ .157 , indicating that that ANCOVA assumption was met.

\section{Summary}

This chapter presents the results of analyses of Research Question 1 (Q1) and Research Question 2 (Q2) for this study. An interpretation of the results of these analyses answering the research questions will be presented in Chapter 5 . 


\section{Chapter Five: Summary, Conclusions, and Recommendations}

\section{Summary}

The purpose of this study was to examine the effect of service-learning on development of critical thinking among a sample of undergraduate students participating in service-learning courses at the Campus Compact-affiliated, public four-year, nonhistorically black university in Maryland with fewer than 5,000 students. This study utilized the California Test of Critical Thinking Skills, to measure the impact of servicelearning on students' critical thinking skills. At present, in the ongoing discussion of the impacts of service-learning on student learning and development, most studies are overly focused on a single measure, and mostly from a rhetorical, not scale-measured perspective. By examining the gains of different types of critical thinking outcomes that occur in various service-learning courses, it is hoped that this study will contribute to the emergence of new research in which more concrete measures set the standard for measuring the learning effectiveness of service-learning on development of critical thinking.

\section{Research questions.}

(RQ 1) Does participation in general education courses that include servicelearning result in gains in critical thinking by students in the courses?

(RQ 2) Are there significant differences in critical thinking outcomes for male students as compared to female students in general education courses that include service-learning? 
General education courses were chosen as the sites for service-learning to enhance the generalizability of the results and to prevent the effect of specialization of field or major interfering with a general assessment of service and learning.

\section{Methodology.}

All Maryland institutions of higher education were disaggregated to identify every non-historically black four year public university that is a member of Campus Compact with a population of 5,000 or less. Frostburg State University is the only college or university that meets all of the criteria for selecting a setting for this study. This university has three colleges and a student population of 4,600 undergraduate and 700 graduate students. General inquiries were made to the institution selected for this sample revealed that they have developed service-learning programs through the agency of Campus Compact.

Phase one consisted of direct administration of the CCTST as a pre-test to students in five general education courses offered at the selected university based upon Campus Compact Coordinator identification of these courses through completion of the Campus Compact Questionnaire (See Appendix B) and Campus Compact Coordinator contact with the instructor.

Phase two consisted of direct post-test administration of the CCTST to students who participated in the direct pre-test administration. Post-test administration utilized the coded identification for each institution and each student who completed the pre-test administration. The researcher directly administered the CCTST post-test to ensure test security essential to this instrument. 
Data were analyzed using two factorial analyses of variance to determine main effects, and interactions: 1) One ANOVA (ANOVA 1) examined the research questions in the context of the scales (skill), and 2) a second ANOVA (ANOVA 2) addressed the two research questions in the framework of the overall score. Results are considered statistically significant at the .05 alpha level.

\section{Conclusions}

(RQ1) Does participation in general education courses that include service learning result in gains in critical thinking by students in the courses?

The findings from the statistical ANOVA 1 CCTST skills/scales results reveal that there is a trend toward significance with post-CCTST results being higher than preCCTST results. The findings from the statistical ANOVA 2 (overall) did not demonstrate a trend toward significance. However, the results were consistent with the skills ANOVA and in the same direction. These findings are consistent with what some researchers who have found that service-learning can indeed promote critical thinking and its component processes (Crews, 2002, Eyler \& Giles, 1999, Jacoby, 2007, Smith, 2004).

(RQ2) Are there significant differences in critical thinking outcomes for male students as compared to female students in general education courses that include service-learning?

The findings from the statistical ANOVA 1 skills/scales demonstrated statistically significant differences. However, these differences were primarily associated with the skills of Analysis and Deduction between males and females. ANOVA 2 (overall) revealed statistically significant differences with the males in this study performing 
higher. While the gender effect was significant, an analysis of covariance (ANCOVA) was also performed to determine if the post-test scores (i.e., dependent variable) would demonstrate this difference, when adjusted for pretest differences. The results of the ANCOVA show that there is not a significant gender difference when the pretest (i.e., control variable) statistical adjustment is implemented. The ANCOVA result supports the perspective that whatever gender differences existed, they were not produced by the service-learning experience during the period when the pre-post measurements/assessments were completed. These findings are generally consistent with the research conducted by Halpern et. al, (2007) and Leach and Good, (2011).

The post hoc analysis of significant omnibus analysis of variance (ANOVA) main skills (scales) are ranked from high to low (see Table 20) as follows:

Table 20

Significant Omnibus ANOVA skills (scales) Ranked High to Low
1. Analysis
2. Induction
3. Inference
4. Evaluation
5. Deduction

It is not clear in this research if reflection was integrated into the service-learning experiences. In summary, the findings from the statistical ANOVA 1 CCTST skills/scales results reveal that there is a trend toward significance with post-CCTST results being higher than pre-CCTST results. The findings from the statistical ANOVA 2 (overall) did not demonstrate a trend toward significance. However, the results were consistent with the skills ANOVA and in the same direction. These findings are consistent with what some researchers who have found that service-learning can indeed promote critical thinking. The finding from the statistical ANOVA 1 skills/scales 
demonstrated statistically significant differences. However, these differences were primarily associated with the skills of Analysis and Deduction. ANOVA 2 (overall) revealed statistically significant differences with the males in this study performing higher. While the gender effect was significant, an analysis of covariance (ANCOVA) was also performed. The ANCOVA supports the perspective that whatever gender differences existed, they were not produced by the service-learning experience. These findings are consistent with my expectations in this research study: that there would be no statistically significant differences between males and females specifically attributable to the service-learning engagement.

\section{Recommendations}

\section{Recommendations for practice.}

This study recommends that colleges and universities consider providing professional development to practitioners that promotes emphasis on critical thinking outcomes across service-learning experiences that are integrated across the curriculum. Such an effort should include ongoing institutional commitment, investment and allocation of time and financial resources for faculty.

$>$ This study also recommends that practitioners consider including assessment of the effect that service-learning has on critical thinking as a component of institutional assessment initiatives to inform ongoing development of best practices.

This study gives further recommendation that universities that integrate service-learning consider developing longitudinal assessment of the gains 
in critical thinking outcomes that students make over the time of their entire collegiate experience.

On the issue of critical thinking, it may be helpful for practitioners to consider curriculum, strategies, and tactics that integrate student development with a clear understanding of what constitutes critical thinking and its importance. This consideration would also allow for continuous refinement and improvement of service-learning initiatives that not only enhances student development of critical thinking skills, but empowers and engages them to be critical thinkers.

An additional recommendation that may be helpful to practitioners is that colleges and universities that integrate service-learning consider development and integration with an electronic portfolio that could be collaboratively developed among faculty and students to provide for a chronological compilation of service-learning experiences. This may allow for determination of cumulative effects that various service-learning experiences have on critical thinking. This strategy could also include institutionally mission driven service-learning and critical thinking outcomes and a student reflective component of their perceived impact that a particular experience had on their own development of critical thinking development. This consideration could also provide opportunities for students to possess a vivid digital compilation that presents and accounts for the real world learning and critical thinking development that were manifest in their service-learning experiences. 


\section{Recommendations for further research.}

This study assessed the effect of service learning on critical thinking outcomes for the period of one academic semester. The development of critical thinking takes time. Further research is recommended that examines the longitudinal cumulative effects that service-learning has on critical thinking and perhaps other outcomes such as development of communication skills, and an openness to diverse points of view over the course of a student's entire college experience. Such research may provide tremendous opportunity to reflect and analyze the diverse empirical effects of service-learning made manifest over time. Moreover, such research may provide robust data to influence instructional decisions and improve the quality of service-learning experiences and their effects on critical thinking.

It is recommended that further research be conducted which examines the effects of various types of learning experiences. While this study provided much needed examination of the effect of service-learning on development of critical thinking among a sample of undergraduate students participating in service-learning courses at the Campus Compactaffiliated, public four-year, non-historically black university in Maryland with fewer than 5,000 students.

This study was limited to students in general education courses. It is further recommended that further research be pursued on the effects of service-learning on student critical thinking outcomes within individual 
disciplines. Such research could offer much needed data for analysis and reflection within individual departmental majors to not only assess the effect of service-learning on critical thinking but also may promote empirical data that supports the development of best practices unique to particular service-learning experiences or departments.

While providing much needed research into the limited population of 5,000 or less, at a non-historically black public 4 year institution, it is recommended that other research be done on other types of higher educational institutions in this important area and on a much broader scale. Specifically, with the clarion call for development of critical thinking skills within our institutions of higher education coupled with six million students enrolled at Campus Compact institutions, seminal research is needed to examine the effects of service learning on critical thinking and other important outcomes. This research would undoubtedly be a costly and vast undertaking. However, with such tremendous commitment, emphasis and investment into service-learning within Campus Compact institutions. In sum, comprehensive research warrants examination to assess the diverse and cumulative effects of service-learning on critical thinking and other learner outcomes. Moreover, this research could offer examination of the effect of service-learning on critical thinking outcomes and student academic success and its influence, if any on other areas such as student retention and graduation rates. 
This study was generally consistent with findings of research that suggested that service-learning has no differential effect on critical thinking in males as compared to females. Further research examining diverse demographic institutions and populations may contribute to the body of knowledge of any cultural, demographic, or geographic effects of service-learning on critical thinking.

While this study confirms the belief that there is a discernable overall significance, the scales effects that demonstrate statistically significant differences among the 5 CCTST skills may both confirm what has been reported in the literature. It is recommended that further investigation into the influence of service-learning programs that clearly articulate and clarify what constitutes critical thinking, including what it looks like in application followed by systematic reflection. The relevance of these findings may confirm what has been reported the literature regarding the need for a period of time to pass before the effects of service learning can be realized (Palomba \& Banta, 1999, p. 235). One of the most important areas of evaluation is critical thinking, for most service-learning pedagogy believes that such reflective events are ideal to encourage critical thinking in students (Jacoby, 2007, p. 3). This would also be consistent with the research by Eyler and Giles which clearly demonstrated that reflection is believed to be the "vital link between service and learning” (Eyler \& Giles, 1999, p. 3). 
It is recommended that the quality of the service-learning component in various courses be studied in terms of the impact on critical thinking skills.

The increases in critical thinking skills among the CCTST scales of Analysis, Induction, Inference, Deduction, and Evaluation are quite valuable changes that occurred in this study. It is further recommended that research be conducted examining changes in each of these complex scales in other service-learning programs. 


\section{REFERENCES}

Adams, E.H., Leader, W., Jain, G. \& Lawrence, C. (2008). Predictive Value of California Critical Thinking Skills Test and First Year Cumulative GPA. Paper presented at Annual Meeting of Annual Association of Collleges of Pharmacy. Retrieved September 9, 2009, from http:www.allacademic.com

Angelis, J. (2003). 10 quality indicators for building community through lifelong service and learning. Available at: 2www.johnsonfdn.org/serving well.html, 1-5.

Astin, A.W. \& Sax, L.J. (1998). How undergraduates are affected by service participation. Journal of College Student Development, 39, 251-263.

Barr, R.B. and Tagg, J. (1995). From teaching to learning- A new paradigm for undergraduate education. Change, 13(25).

Bartlett, D. \& Cox, P. (2002). Measuring Change in Students' Critical Thinking Ability. Journal of Allied Health, 31(2), 64-69.

Baugley, J. Understanding Statistical Power in the Context of Applied Research. Applied Ergonomics, 35(1), 73-80.

Berson, J.S. \& Tounkin, W.F. (1998). Doing well by doing good: a study of the effects of a service-learning experience on student success. Association for the Study of Higher Education, annual meeting, November 5-8, 4-18.

Boyer, Ernest. (1990). Scholarship Reconsidered-Priorities of the Professoriate. Princeton: New Jersey: Princeton University Press.

Boyle, H. \& Hollander, E. (1999). Wingspread Declaration on renewing the civic mission of the American research university. Campus Compact, 7-15. 
Boyle-Baise, M. \& Efiom, P. (2000). The construction of meaning: Learning from service learning. In, O’Grady, C. R. Integrating service learning and multicultural education in colleges and universities. Mahwah, New Jersey: Lawrence Erlbaum Associates Publishers, 209-226.

Bringle, R.G. \& Hatcher, J.A. (1996). Journal of Higher Education, 67, 1-15.

Burr, K.L. (2002). Problems, politics and possibilities of a progressive approach to service learning in a community college: a case study. Journal of Industrial Teacher Education, 36, 1-23.

Campus Compact. (2003). Building the service-learning pyramid. Campus Compact, available at: $\underline{\text { www.compact.org/faculty/specialreport.html, 1-7. }}$

Campus Compact. (2003) Assessing Service-learning and Civic Engagement Providence: Campus Compact, Brown University.

Caplan, P.J. \& Caplan, J.B. (2009). Thinking Critically about Research on Sex and Gender. Upper Saddle River: Pearson.

Carter-Wells, J. (1996). Raising expectations for critical reading. In, Jones, E.A., Preparing Competent College Graduates: Setting Hew and Higher Expectations for Student Learning. San Francisco: Jossey-Bass Publishers, 45-54.

Chickering, A. \& Gamson, Z.F. (1987). Seven principles for good practice in undergraduate education. American Association for Higher Education Bulletin, March, 1-6. 
Click, B.A.L. (1996). Educating students to write effectively. In, Jones, E.A., Preparing Competent College Graduates: Setting Hew and Higher Expectations for Student Learning. San Francisco: Jossey-Bass Publishers, 31-44.

Cohen, J. (1992) A Power Primer, Psychological Bulletin, 1(112), pp. 155-172.

Cone, K.J. (2000). The development and testing of an instrument to measure decisionmaking in emergency department triage nurses. Unpublished doctoral dissertation.

Conrad, D. \& Hedin, D. (2003). Executive Summary of the final Report of the Experiential Education Evaluation Project.

Crews, J. (2002). Higher Education Service-learning sourcebook. Westport: Oryx Press. Dewey, J. (1938). Experience and Education. New York: Collier Books.

Dougherty, B.C. \& Fantaske, P. (1996). Defining expectations for problem-solving skills. In, Jones, E.A., Preparing Competent College Graduates: Setting New and Higher Expectations for Student Learning. San Francisco: Jossey-Bass Publishers, 55-66.

Ehrlich, T. (1996). Foreword. In, Jacoby, B., Service-Learning in Higher Education. San Francisco: Jossey-Bass, xi-xvi.

Erdfelder, F, Lang, E., \& Buchner, A., (2007) G* Power 3: A flexible statistical power analysis program for social, behavioral, and biomedical sciences. Behavioral Research Methods, 175-191. 
Erickson, J.A., O’Connor, S.E. (2000). Service-learning: does it promote or reduce prejudice? In, O’Grady, C. R. Integrating service learning and multicultural education in colleges and universities. Mahwah, New Jersey: Lawrence Erlbaum Associates Publishers, 59-70.

Eyler, J. \& Giles, D.E. (1999). Where's the Learning in Service-Learning? San Francisco: Jossey-Bass.

Eyler, J., Giles, D.E. \& Braxton, J. (1997). The impact of service-learning on college students. Michigan Journal of Community Service Learning, 19-35.

Facione, P. (2008). California Critical Thinking Skills Test Manual. (Available from California Academic Press, 217 La Cruz Avenue, Millbrae, CA 94030)

Facione, P. (1990). The California Critical Thinking Skills Test-Factors of Predictive Critical Thinking Skills (College Level-Technical Report \#2). Millbrae, CA.: California Academic Press.

Facione, P.A. \& Facione, N.C. (1992). California Critical Thinking Skills Disposition Inventory, (College Level-Technical Report). Millbrae, CA: California Academic Press

Field, A. (2005). Discovering Statistics Using SPSS Statistics (2 ed.). London: Sage.

Fink, L.D. (2003). Creating Significant Learning Experiences. San Francisco: JosseyBass.

Frankel, J.R. \& Wallen, N.E. (2000). How to Design and Evaluate research in Education. Boston: McGraw-Hill. 
Giles, D.E. \& Eyler, J. (1994). The theoretical roots of service-learning in John Dewey: toward a theory of service learning. Michigan Journal of Community Service Learning, 77-85.

Gugerty, C.R. \& Swezy, E.D. (1996). Developing campus-community relationships. In, In, Jacoby, B., Service-Learning in Higher Education. San Francisco: JosseyBass, 92-112.

Halpern, D. (2007). The Nature and Nurture of Critical Thinking-Critical Thinking in Psychology. New York: Cambridge University.

Halpern, D. Benbow, C., Geary, D., Gur, R., Hyde, J., \& Gernsbacher, M. (2007). The Science of Sex Differences in Mathematics. Psychological Science in the Public Interest, 8(1), 1-51.

Heffernan, K. (2001). Service-learning in higher education. National Campus Compact, 2-8.

Holland, B. (1997). Analyzing institutional commitment to service: a model of key organizational factors. Michigan Journal of Community Service Learning, 30-39.

Hollander, E., \& Saltmarsh, J. (2005). The Engaged University. Retrieved September, 1, 2008 from www.aaup./org/publications/Academe2000/00ja/JA00Holl.htm>

Huba., M.E. \& Freed, J.E. (2000). Learner-Centered Assessment on College Campuses. Boston: Allyn and Bacon, 215-222.

Jacoby, B. (1996). Preface. In, Jacoby, B., Service-Learning in Higher Education. San Francisco: Jossey-Bass, xvii-xxi

Jacoby, B. (1996). Service-learning in today’s higher education. In, Jacoby, B., ServiceLearning in Higher Education. San Francisco: Jossey-Bass, 3-25. 
Jacoby, B. (2007). Building Partnerships in Service-learning. San Francisco: JosseyBass.

Jones, E.A. (1996). National and state policies affecting learning expectations. In, Jones, E.A., Preparing Competent College Graduates: Setting Hew and Higher Expectations for Student Learning. San Francisco: Jossey-Bass Publishers, 7-18.

Kellogg Commission. (1999). Returning to our Roots-The Engaged Institution Washington, D.C.: National Association of State Universities and Land Grant Colleges, Office of Public Affairs.

Kelshaw, T., Lazarus, F., and Minier, J. (2009). Partnerships for Service-learning. SanFrancisco: Jossey-Bass.

Kennison, M. (2006). The Evaluation of Students Reflective Writing for Evidence of Critical Thinking. Nujrsing Education Perspectives, 27(5), 269-273.

Khalli, H. \& Hosselu, Z. (2003). Investigation of reliability, validity and normality Persian Versian of the California Critical Thinking SKills Test. Journal of Medical Education, 3(1), 16-19.

King, P.M. \& Kitchner, K.S. (1994). Understanding and Promoting Intellectual Growth and Critical Thinking. San Francisco: Jossey Bass.

Kuh, G.D. (1994). Student learning outside the classroom: Transcending artificial boundaries. ERIC Digest, available at: www.ed.gov/databases/ERIC_Digests/ed394443.html, 1-4.

LaFountain, R. \& Bartos, R. (2002). Research and statistics made meaningful in counseling and student affairs. Pacific Grove, CA.: Brooks-Cole Thomson Learning. 
Leach, B., \& Good, D. (2011). Critical Thinking as Related to University Students' Gender and Academic Discipline. International Journal of Humanities and Social Science, 1(21), 4-6.

Levine, A. \& Cureton, J. (1998). When Hope and Fear Collide: A portrait of Today's College Student. San Francisco: Jossey-Bass, 178.

Markus, G.B., Howard, J.P.F. \& King, D.C. (1993). Integrating community service and classroom instruction enhances learning: results from an experiment. Educational Evaluation and Policy Analysis, 15, 1-16.

McEwen, M.E. (1996). Enhancing student learning and development through servicelearning. In, Jacoby, B., Service-Learning in Higher Education. San Francisco: Josses-Bass, 53-91.

Merizow, J., \& Taylor, E. (2009). Transformative Learning in Practice. San Francisco: Jossey-Bass.

Mintz, S.D. \& Hesser, G.W. (1996). Principles of good practice in service-learning. In, Jacoby, B., Service-Learning in Higher Education. San Francisco: Jossey-Bass, 26-52.

Moore, D.T. (1981). Discovering the pedagogy of experience. Harvard Educational Review, 51, 286-300.

Moore, B. \& Parker, R. (2009). Critical Thinking (9th ed.). New York: McGraw-Hill Higher Education.

Myers-Lipton, S.J. (1994). The Effects of Service-Learning on College Students’ Attitudes Toward Civic Responsibility, International Understanding and Racial Prejudice. Boulder: University of Colorado. 
Office of Community Service-Learning. (2000). Establishing benchmarks for the engaged campus: the University of Maryland report. Office of Community Service-Learning report, available at: www.cacs.umd.edu/csp/servicelearning/engaged.html, 1-17.

O’Grady, C. (2000). Integrating service-learning and multicultural education an overview. In, O’Grady, C. R. Integrating service learning and multicultural education in colleges and universities. Mahwah, New Jersey: Lawrence Erlbaum Associates Publishers, 1-19.

Palomba, C.A. \& Banta, T.W. (1999). Assessment Essentials: Planning, implementing and improving assessment in higher education. San Francisco: Jossey-Bass.

RAND. (1999). Combining Service and Learning in Higher Education (0-8330-2725-5). Santa Monica: RAND.

Rice, K. \& Pollack, S. (2000). Developing a critical pedagogy of service learning: preparing self-reflective, culturally aware and responsive community participants. In, O’Grady, C. R. Integrating service learning and multicultural education in colleges and universities. Mahwah, New Jersey: Lawrence Erlbaum Associates, 115-134.

Rosenberger, C. (2000). Beyond empathy: Developing critical consciousness through service learning. In, O’Grady, C. R. Integrating service learning and multicultural education in colleges and universities. Mahwah, New Jersey: Lawrence Erlbaum Associates Publishers, 23-43.

Schwartzman, R. (2001). Service-learning responds to technological enchantment and intellectual isolation. College Student Journal, 35, 1-9. 
Sigmon, R. (1996). Journey to Service-Learning. Washington, D.C.: Council of Independent Colleges.

Smith, P. (2004). The Quiet Crisis-How higher education is failing America. Bolton: Massachusetts: Anker.

Springer, D. (2007). The Scholarship of Teaching and Learning in Higher Education an evidence based perspective. Amsterdam: Dordrecht.

Srinivasn, S. \& Crooks, S. (2005). Does Gender Influence Critical Thinking Attitudes? (Society for Technology \& Teacher Education International Conference-2005). Phoenix, Arizona:

Sullivan, T.J. (2001). Methods of Social Research. Orlando: Harcourt.

Walsh, W. \& Betz, N. Tests and Assessment. Upper Saddle River, NJ.: Prentice-Hall.

Yeh, M.L. (1996). Translation and Validation of the California Critical Thinking Skills Inventory. Unpublished doctoral dissertation, St. Louis University. 


\title{
APPENDIX A
}

\section{Pre Service-Learning Experience Cover Letter}

\author{
to the Campus Compact Coordinator
}

Date:

Address:

Dear Campus Compact Coordinator

Thank you for your cooperation, assistance, and support of my doctoral research with the West Virginia University Department of Advanced Educational Studies. I appreciate your assistance in identification and selection of general education courses that have integrated service-learning based upon the best practices of Campus Compact. The purpose of my study is to examine the connection between service-learning and critical thinking outcomes in general education courses. This research is being conducted by Larry Smith, a doctoral candidate, to fulfill the requirements for a degree in Educational Leadership Studies in the Department of Human Resources and Education at West Virginia University under the supervision of Dr. Ernest Goeres and Dr. Dan Hursh. My research has three major parts.

1. As the Institutional Director of Campus Compact, please complete the attached questionnaire which will take 5 minutes or less to complete. Your responses will be held confidential and your institution will not be named in my dissertation. Not less than three general education courses which integrate service learning will be identified by you as the institutional director of Campus Compact from your identification of general education courses that integrate service-learning consistent with the best practices of Campus Compact. As the Campus Compact institutional director your assessment will rank the general education courses that integrate service-learning that are believed to produce the greatest gains in critical thinking outcomes by students over time. This process will allow the feasibility of identification and selection of general education courses that have service-learning integrated consistent with the literature. From this identification of course protocol not less than 120 students in total in not less than 5 courses will be selected for this sample of my study. Upon completion of my study, I will provide you with an Executive Summary of my research. 
2. The next phase of my research will consist of students identified the protocol cited above, with not less than 120 students in not less than 3 general education courses completing the California Critical Thinking Skills Test. I will coordinate with the teachers of each class to schedule a time to for me to visit each class for my direct administration of this test as a pre-test during the prior to the service-learning experience. When I arrive I will read the student a cover letter and California Critical Thinking Skills Test directions aloud inviting students to participate. I need to have not less than 120 students in not less than 3 general education courses to participate in my study. Each student receives a cover letter, student demographic questionnaire, (I have provided a copy for your review). I will directly administer and take the student answer sheets and completed demographic questionnaire with me.

3. In the final phase of my research I will again coordinate a time to visit the general education courses to administer the California Critical Thinking Skills Test as a post-test. This phase needs to be completed by the end of the semester. Again, I will read the student cover letter and CCTST directions aloud to students inviting them to participate.

The responses to the CCTST will be held confidential and your institution, teachers, and students will not be mentioned by name in my dissertation.

Should you have any questions, please do not hesitate to contact me at (301) 6974297 or my supervisor, Dr. Ernest Goeres or Dr. Dan Hursh, at (304) 293-3707. For information regarding your rights as a research subject, you may contact the Office of Research Compliance at 304-293-7073. Again, thank you for your cooperation, support and assistance.

With deep gratitude I remain,

Sincerely,

Larry Smith

Doctoral Candidate

West Virginia University

threemusketeers@atlanticbb.net 


\section{APPENDIX B}

\section{Campus Compact Coordinator Questionnaire}

College Name

Agrees to participate? Yes

No

Have you identified not less than 3 general education courses with not less than 120 students that integrate service learning based upon the best practices of campus compact?

Yes No

Based upon your identification of these courses consistent with the best practices of Campus Compact and your contact with the instructor, will the instructor of these courses be willing to allow the researcher to contact him to schedule a visit to the classes to conduct pre and post assessment using the California Critical Thinking Skills Test?

Yes No 


\title{
APPENDIX C
}

\section{Student Information and Consent Form}

\section{CONSENT AND INFORMATION FORM}

\author{
Service-learning and critical thinking outcomes \\ in Maryland four year public university general \\ education courses
}

\section{Introduction}

I, , have been invited to participate in this research study which has been explained to me by Larry Smith. This research is being conducted by Larry Smith, a doctoral candidate, to fulfill the requirements for a doctoral dissertation in Educational Leadership Studies in the Department of Human Resources and Education at West Virginia University, under the supervision of Dr. Ernest Goeres and Dr. Dan Hursh.

\section{Purpose of the study}

The purpose of this study is to determine if students who participate in general education courses that integrate service-learning demonstrate gains in critical thinking outcomes over time. The population studied will be Maryland four year college students enrolled in general education courses that integrate service-learning

\section{Description of Procedures}

I have been told that I will complete 3 response sheets. This sheet, the Consent and Information Sheet which will take no more than 5 minutes to complete and two response sheets, each to the California Critical Thinking Skills Test, which will take no more than 45 minutes to complete. I will complete one today and another that will be administered to me at the end of the semester. I have been told that I may see the California Critical Thinking Skills Test before signing this consent and that I do not have to answer all the questions if I decide to participate. Approximately 120 students are expected to participate in this study. Your participation will consist of participating in a pre and post administration of the California Test of Critical Thinking Skills. The tests will be coded to insure your complete anonymity.

Submission date Page 1 of 3 Initials Date 


\section{Risks and Discomforts}

There are no known or expected risks from participating in this study.

Alternatives

I understand that I do not have to participate in this study.

\section{Contact Persons}

For more information about this research, I can contact Larry Smith, at 301-697-4297, or his supervisors, Dr. Ernest Goeres or Dr. Dan Hursh at 304293-3707. For information regarding my rights as a research subject, I may contact the Office of Research Compliance at 304-293-7073.

\section{Confidentiality}

I understand that any information about me obtained as a result of my participation in this research will be kept as confidential as legally possible. I understand that my research records and test results, just like hospital records, may be subpoenaed by court order or may be inspected by the study sponsor or federal regulatory authorities (including the FDA if applicable) without my additional comment. In any publications that result from this research, neither my name nor any information from which I might be identified will be published without my consent.

Submission date: Page 2 of 3 Initials Date 


\section{Voluntary Participation}

Participation in this study is voluntary. I understand that I am free to withdraw my consent to participate in this study at any time and that such refusal to participate will not affect any class standing or grades. Refusal to participate or withdrawal will involve not penalty to me. I have been given the opportunity to ask questions about the research, and I have received answers concerning areas I did not understand. In the event that new information becomes available that may affect my willingness to continue to participate in the study, this information will be given to me so that I may make an informed decision about my participation.

Upon signing this form, I will receive a copy.

I willingly consent to participate in this research.

$\overline{\text { Signature of Subject or Subjects Legal Representative }}$

Signature of Investigator or Co-Investigator

Submission Date
Page 3 of 3

\section{Date \\ Time}

Date
Time 


\section{APPENDIX D}

\section{Post-test Cover Letter to Students}

Date:

\section{Dear Student:}

Thank you for participating in phase one of my study. I need your help to complete the final step of the study in Service-Learning and Critical Thinking Outcomes in Maryland General Education Courses. This research is being conducted by Larry Smith, a doctoral candidate, to fulfill the requirements for a degree in Educational Leadership Studies in the Department of Human Resources and Education at West Virginia University, under the supervision of Dr. Ernest Goeres and Dr. Dan Hursh. You have selected to participate in this study because you are enrolled in a general education course that integrates service-learning at your college.

Attached you will find the final response sheet. This final response sheet will correspond to the administration of the California Critical Thinking Skills test and will take no more than 40 minutes to complete. When you are finished your response sheets, I will collect the question booklet and answer sheet from you.

Your responses to the questions on your response sheet will be confidential and your participation is voluntary. If you choose, you do not have to answer every question. Your choice not to participate in this study will not jeopardize your course or grade standing.

For more information about this research, please contact, Larry Smith, at (301) 697-4297 or his supervisors, Dr. Ernest Goeres or Dr. Dan Hursh at (304) 293-3707. For information regarding your rights as a research subject, you may contact the Office of Research Compliance at 304-293-7073.

Thank you for your help,

Larry Smith

Doctoral Candidate

West Virginia University 